\title{
A Model for Evaluating Effects of Climate, Water Availability, and Water Management on Wetland Impoundments-A Case Study on Bowdoin, Long Lake, and Sand Lake National Wildlife Refuges
}

Scientific Investigations Report 2013-514

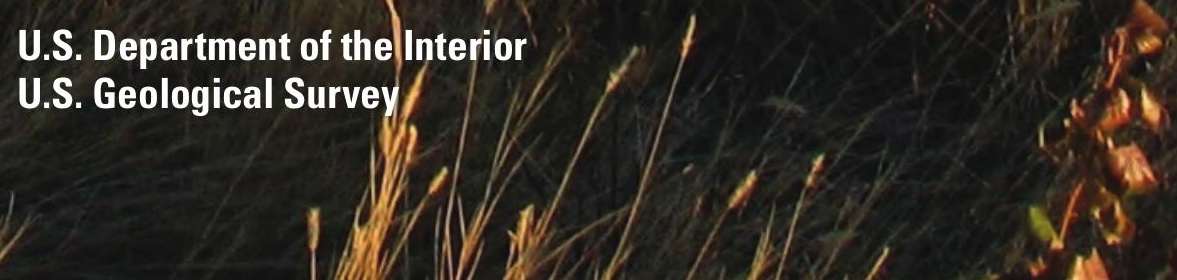


Cover. Lake Bowdoin, Bowdoin National Wildlife Refuge, Montana, October 2011. 


\section{A Model for Evaluating Effects of Climate, Water Availability, and Water Management on Wetland Impoundments-A Case Study on Bowdoin, Long Lake, and Sand Lake National Wildlife Refuges}

By Brian A. Tangen, Robert A. Gleason, and John F. Stamm

Scientific Investigations Report 2013-5114 


\title{
U.S. Department of the Interior SALLY JEWELL, Secretary
}

\section{U.S. Geological Survey Suzette M. Kimball, Acting Director}

\author{
U.S. Geological Survey, Reston, Virginia: 2013
}

For more information on the USGS - the Federal source for science about the Earth, its natural and living resources, natural hazards, and the environment, visit http://www.usgs.gov or call 1-888-ASK-USGS.

For an overview of USGS information products, including maps, imagery, and publications, visit http://www.usgs.gov/pubprod

To order this and other USGS information products, visit http://store.usgs.gov

Any use of trade, firm, or product names is for descriptive purposes only and does not imply endorsement by the U.S. Government.

Although this information product, for the most part, is in the public domain, it also may contain copyrighted materials as noted in the text. Permission to reproduce copyrighted items must be secured from the copyright owner.

Suggested citation:

Tangen, B.A., Gleason, R.A., and Stamm, J.F., 2013, A model for evaluating effects of climate, water availability, and water management on wetland impoundments - A case study on Bowdoin, Long Lake, and Sand Lake National Wildlife Refuges: U.S. Geological Survey Scientific Investigations Report 2013-5114, 37 p., http://pubs.usgs.gov/ sir/2013/5114/. 


\section{Contents}

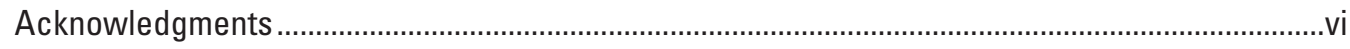

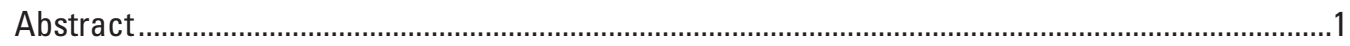

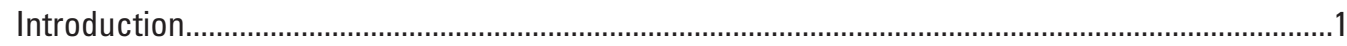

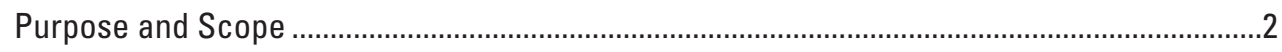

Climate Trends and Projections............................................................................................

Wetland Management on Federal Lands..............................................................................

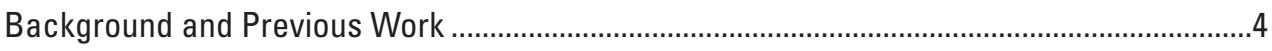

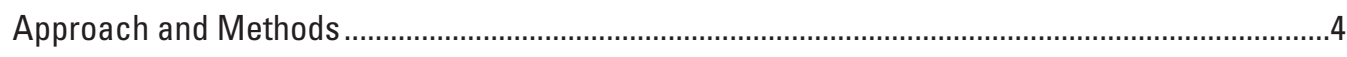

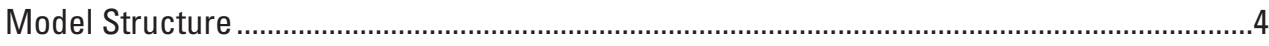

Model Validation Methods and Study Sites …………………...............................................

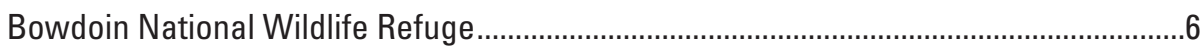

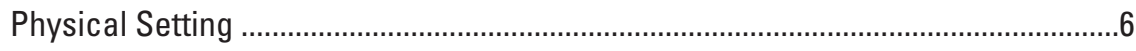

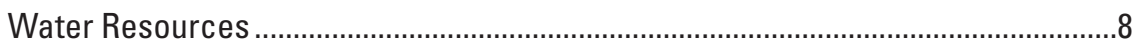

Management and Environmental Concerns..............................................................

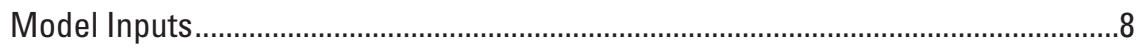

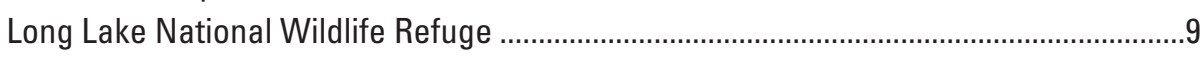

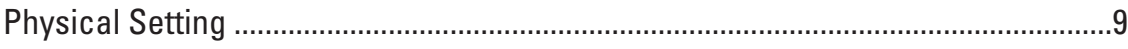

Water Resources .................................................................................................11

Management and Environmental Concerns..............................................................11

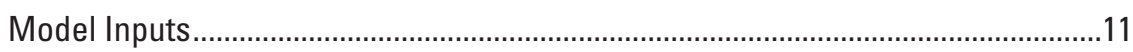

Sand Lake National Wildlife Refuge .........................................................................12

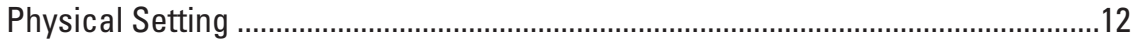

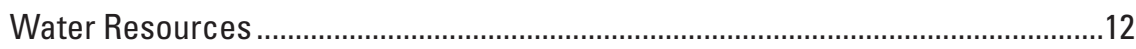

Management and Environmental Concerns.......................................................12

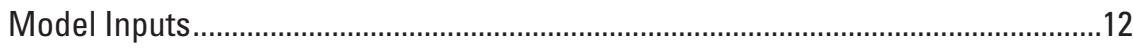

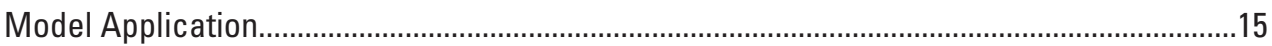

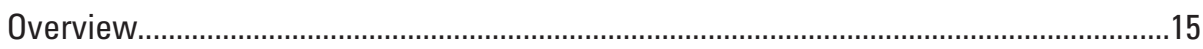

Methods

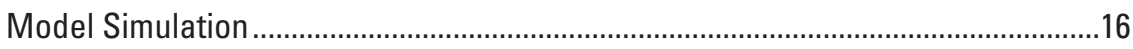

Model Inputs................................................................................................

Simulated Future Climate Inputs ...............................................................................17

Validation and Application of the Water and Salt Balance Model....................................................18

Results of Model Validation ............................................................................................18

Bowdoin National Wildlife Refuge.............................................................................18

Long Lake National Wildlife Refuge ...........................................................................20

Sand Lake National Wildlife Refuge ..........................................................................20

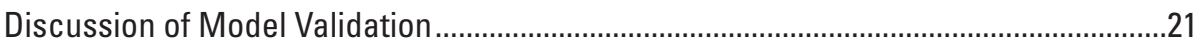

Results of Model Application to Bowdoin National Wildlife Refuge ......................................23

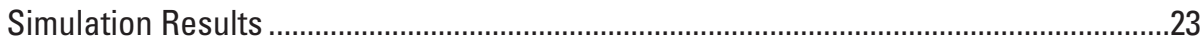

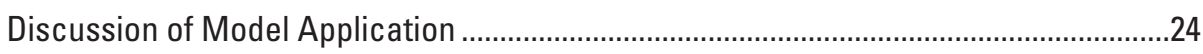

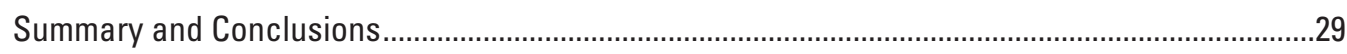

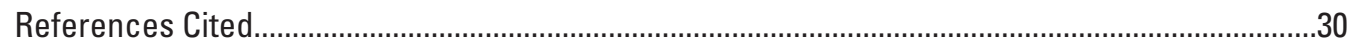

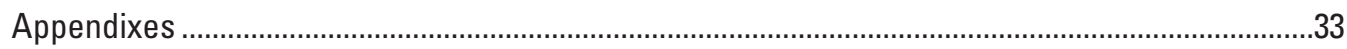




\section{Figures}

1. Map showing location of Bowdoin, Long Lake, and Sand Lake National Wildlife Refuges in the northern Great Plains .2

2. Graph showing relations between specific conductance and total dissolved solids ......5

3. Map showing location and primary management units of Bowdoin National Wildlife Refuge.

4. Graph showing Lake Bowdoin pool elevations and stream discharge from Beaver

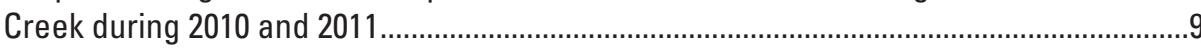

5. Map showing location and primary management units of Long Lake National Wildlife Refuge

6. Map showing location and primary management units of Sand Lake National Wildlife Refuge.

7. Graph showing Palmer Modified Drought Index values for northeastern South Dakota and discharge for the James River from October 1, 1981, to June 1, 2012.........14

8. Graph showing Palmer Modified Drought Index values for north-central Montana and mean monthly specific conductance for Lake Bowdoin.

9. Graphs showing outputs from the Weather Research and Forecasting model simulation.

10. Graph showing modeled and measured pool elevation and specific conductance for Lake Bowdoin from May 14 to November 9, 2010, and May 10 to October 25, 2011

11. Graph showing modeled mean water depth and surface areas for Lake Bowdoin from May 14 to November 9, 2010, and May 10 to October 25, 2011

12. Graph showing modeled and measured pool elevation and specific conductance for Unit 1 of Long Lake National Wildlife Refuge from April 23 to November 19, 2010, and May 11 to October 26, 2011

13. Graph showing modeled mean water depth and surface areas for Unit 1 of Long Lake National Wildlife Refuge from April 23 to November 19, 2010, and May 11 to October 26, 2011 ....

14. Graph showing modeled and measured pool elevation and specific conductance for Sand Lake National Wildlife Refuge from May 17 to November 22, 2010, and May 12 to October 27, 2011

15. Graph showing modeled mean water depth and surface areas for Sand Lake National Wildlife Refuge from May 17 to November 22, 2010, and May 12 to October 27, 2011

16. Graphs showing results from the 50 -year model simulations of Lake Bowdoin..............25

17. Graphs showing results from the single-year model simulations of Lake Bowdoin .......26

18. Graphs showing results from the 50-year model simulations of Lake Bowdoin that included Beaver Creek floods

19. Graph showing specific conductance from the 50-year model simulations of Lake Bowdoin overlain with salinity category boundaries.

20. Graph showing specific conductance from the 50-year model simulations of Lake Bowdoin that included Beaver Creek floods overlain with salinity category boundaries 


\section{Table}

1. Summary statistics comparing measured values to the 2010 and 2011 model simulations of Bowdoin, Long Lake, and Sand Lake National Wildlife Refuges

\section{Conversion Factors and Datums}

Inch/Pound to SI

\begin{tabular}{lcl}
\hline \multicolumn{1}{c}{ Multiply } & \multicolumn{1}{c}{ By } & \multicolumn{1}{c}{ To obtain } \\
\hline inch (in.) & Length & \\
inch (in.) & 2.54 & centimeter $(\mathrm{cm})$ \\
foot (ft) & 25.4 & millimeter $(\mathrm{mm})$ \\
mile (mi) & 0.3048 & meter $(\mathrm{m})$ \\
\hline & 1.609 & kilometer $(\mathrm{km})$ \\
\hline acre & Area & \\
acre & 0.4047 & hectare $(\mathrm{ha})$ \\
acre & 0.4047 & square hectometer $\left(\mathrm{hm}^{2}\right)$ \\
square mile $\left(\mathrm{mi}^{2}\right)$ & 0.004047 & square kilometer $\left(\mathrm{km}^{2}\right)$ \\
\hline & 2.590 & square kilometer $\left(\mathrm{km}^{2}\right)$ \\
\hline acre-foot $($ acre-ft) & Volume & \\
\hline & 0.001233 & cubic hectometer $\left(\mathrm{hm}^{3}\right)$ \\
\hline acre-foot per day (acre-ft/d) & Flow rate & \\
cubic foot per second $\left(\mathrm{ft}^{3} / \mathrm{s}\right)$ & 0.01427 & cubic meter per second $\left(\mathrm{m}^{3} / \mathrm{s}\right)$ \\
\hline & 0.02832 & cubic meter per second $\left(\mathrm{m}^{3} / \mathrm{s}\right)$ \\
\hline ton, short $(2,000 \mathrm{lb})$ & Mass & \\
\hline
\end{tabular}

Temperature in degrees Celsius $\left({ }^{\circ} \mathrm{C}\right)$ may be converted to degrees Fahrenheit $\left({ }^{\circ} \mathrm{F}\right)$ as follows: ${ }^{\circ} \mathrm{F}=\left(1.8 \times^{\circ} \mathrm{C}\right)+32$

Temperature in degrees Fahrenheit $\left({ }^{\circ} \mathrm{F}\right)$ may be converted to degrees Celsius $\left({ }^{\circ} \mathrm{C}\right)$ as follows: ${ }^{\circ} \mathrm{C}=\left({ }^{\circ} \mathrm{F}-32\right) / 1.8$

Vertical coordinate information is referenced to the North American Vertical Datum of 1988 (NAVD 88).

Horizontal coordinate information is referenced to the North American Datum of 1983 (NAD 83).

Specific conductance is given in microsiemens per centimeter at 25 degrees Celsius $(\mu \mathrm{S} / \mathrm{cm}$ at $\left.25^{\circ} \mathrm{C}\right)$.

Concentrations of chemical constituents in water are given either in milligrams per liter (mg/L) or micrograms per liter $(\mu \mathrm{g} / \mathrm{L})$. 


\section{Acknowledgments}

Funding for this project was provided by the U.S. Geological Survey (USGS). We thank Charles Dahl and Raymond Finocchiaro for assisting with field work and Betty Euliss for geographic information system support. We thank and Jason Alexander and Peter McCarthy for comments on a previous version of this report.

We thank all of the staff from Bowdoin, Long Lake, and Sand Lake National Wildlife Refuges for providing expertise, data, and field assistance throughout the duration of this project. This work would not have been possible without their support and cooperation. Stan Jones, hydrologist with Montana Department of Natural Resources and Conservation, converted the original Hamilton and others (1989) model to an Excel format, and we thank Stan and John Simpson (U.S. Fish and Wildlife Service) for providing information pertaining to this converted model. Lastly, we thank Murray Laubhan for comments on a previous version of this report. 


\title{
A Model for Evaluating Effects of Climate, Water Availability, and Water Management on Wetland Impoundments-A Case Study on Bowdoin, Long Lake, and Sand Lake National Wildlife Refuges
}

\author{
By Brian A. Tangen, Robert A. Gleason, and John F. Stamm
}

\section{Abstract}

Many wetland impoundments managed by the U.S. Fish and Wildlife Service (USFWS) National Wildlife Refuge System throughout the northern Great Plains rely on rivers as a primary water source. A large number of these impoundments currently are being stressed from changes in water supplies and quality, and these problems are forecast to worsen because of projected changes to climate and land use. For example, many managed wetlands in arid regions have become degraded owing to the long-term accumulation of salts and increased salinity associated with evapotranspiration. A primary goal of the USFWS is to provide aquatic habitats for a diversity of waterbirds; thus, wetland managers would benefit from a tool that facilitates evaluation of wetland habitat quality in response to current and anticipated impacts of altered hydrology and salt balances caused by factors such as climate change, water availability, and management actions.

A spreadsheet model that simulates the overall water and salinity balance (WSB model) of managed wetland impoundments is presented. The WSB model depicts various habitat metrics, such as water depth, salinity, and surface areas (inundated, dry), which can be used to evaluate alternative management actions under various water-availability and climate scenarios. The WSB model uses widely available spreadsheet software, is relatively simple to use, relies on widely available inputs, and is readily adaptable to specific locations. The WSB model was validated using data from three National Wildlife Refuges with direct and indirect connections to water resources associated with rivers, and common data limitations are highlighted. The WSB model also was used to conduct simulations based on hypothetical climate and management scenarios to demonstrate the utility of the model for evaluating alternative management strategies and climate futures. The WSB model worked well across a range of National Wildlife Refuges and could be a valuable tool for USFWS staff when evaluating system state and management alternatives and establishing long-term goals and objectives.

\section{Introduction}

The U.S. Fish and Wildlife Service's (USFWS) National Wildlife Refuge System (NWRS) encompasses over 150 million acres of diverse aquatic and terrestrial habitats throughout the United States that support a rich variety of wildlife and are critical to sustaining much of the Nation's biotic diversity. In the northern Great Plains (fig. 1), a large number of national wildlife refuges (NWR) were established during the drought years of the 1930s to provide sanctuary and breeding ground for migratory birds and other wildlife. Accordingly, a substantial number of these NWRs were located in river flood plains, and many contain managed lakes or impoundments that require inflows or diversions from lotic systems for primary water supply. Hence, the original design and placement of many NWRs and managed impoundments were influenced by climatic variation and the selection of these sites was predicated on the long-term availability of water from reliable sources.

Changes in climate can affect natural wetland and terrestrial ecosystems, as well as industry (for example, agriculture, forestry, fisheries) and municipalities (Field and others, 2007). Recently, widespread concerns over global climate change have prompted syntheses of research on the mechanisms of change (Solomon and others, 2007) and the potential effects to ecological systems in the United States and northern Great Plains (Bridgham and others, 1995; Field and others, 2007; Brekke and others, 2009; Karl and others, 2009; Johnson and others, 2010). The most direct links between climate and aquatic ecosystems are hydrology and phenology. Changes in climate would potentially alter the hydrologic budget on a range of scales, from small wetlands (Johnson and others, 2010) to larger watersheds and their associated lakes and streams. Similarly, changes in regional temperature patterns associated with climate change would have a variety of effects ranging from altered rates of evapotranspiration to a shift in the timing of snowfall and spring snowmelt. Such changes could subsequently affect plant phenology, primary and 


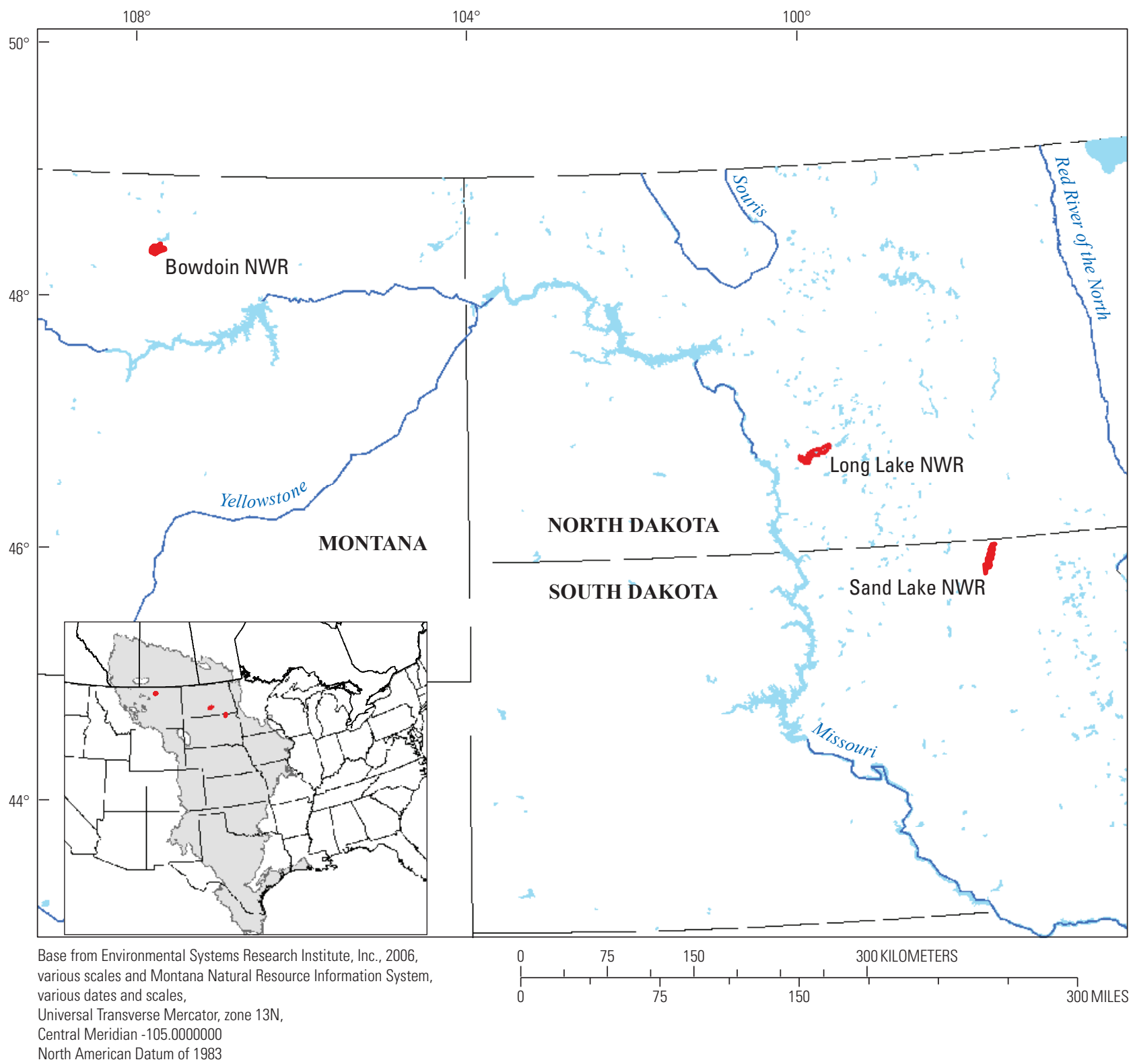

Figure 1. Location of Bowdoin, Long Lake, and Sand Lake National Wildlife Refuges (NWR) in the northern Great Plains.

secondary production, and ultimately, the distribution and size of wildlife populations (Field and others, 2007). Moreover, these types of direct impacts can be exacerbated through interactions with indirect effects associated with wetland management and ecosystem change.

\section{Purpose and Scope}

The purpose of this report was to establish the framework for a tool that could be used to assess the state of an impoundment and impacts of climate or management on specific habitat and water-quality parameters. The proposed model framework uses a water and mass balance approach to simulate water and salinity levels of individual managed impoundments, which regulate various habitat (for example, water depth, salinity, inundated and dry surface areas) and water-quality characteristics.

Three NWRs were selected to test and validate the proposed model: Bowdoin NWR (BNWR) (Montana), Long Lake NWR (LLNWR) (North Dakota), and Sand Lake NWR (SLNWR) (South Dakota) (fig. 1). However, the models and concepts discussed throughout this report are applicable to managed impoundments throughout the NWRS. The refuges considered for this report span the regional precipitation gradient that increases from west to east, have direct and indirect relations to water resources associated with rivers, and are influenced by rivers with downward, neutral, or upward streamflow trends over approximately the past 50 years (Anderson and Norton, 2007; Anderson and others, 2008). 


\section{Climate Trends and Projections}

Climate trends in the United States indicate that precipitation and average temperature have increased over the past 50 years, but these trends vary greatly among regions (Anderson and Woosley, 2005; Karl and others, 2009). The northern Great Plains region of the United States (fig. 1) is characterized by an increasing precipitation gradient from west to east. Observed trends in the region for the 50-year period from 1958 to 2008 indicate that the Dakotas and Minnesota are becoming wetter and Montana is becoming drier. Average temperatures in the region have increased over the same period (Karl and others, 2009). Anderson and Woosley (2005) suggest downward trends in precipitation since 1971 for Montana, Wyoming, western North Dakota, and western and southern Nebraska, and upward trends in South Dakota, southeastern North Dakota, and northeastern Nebraska. Badh and Akyuz (2010) examined precipitation records from eight stations in North Dakota and did not identify an overall trend in annual precipitation. Millett and others (2009) evaluated climate trends from 1906 to 2000 at 18 climate stations in the Prairie Pothole Region. Precipitation increased by 1.9 inches (in.) (9 percent) with all of the significant increases (10 stations) located in the eastern part of the Prairie Pothole Region, and minimum daily temperature increased 1.8 degrees Fahrenheit $\left({ }^{\circ} \mathrm{F}\right)$ and maximum daily temperature decreased $0.36^{\circ} \mathrm{F}$ (Millett and others, 2009). Karl and others (2009, p. 28) estimate that average temperature from 1993 to 2008 in the Missouri River drainage basin was 1.08 to $3.06^{\circ} \mathrm{F}$ warmer than the average for 1961-1979, with greatest warming in areas of the northern Missouri River watershed.

Climate projections for the Great Plains forecast increased temperatures and precipitation in the north, and forecast a higher frequency of extreme weather and climate events, such as heavy precipitation or extended drought, throughout the region (Karl and others, 2009). Additionally, the percentage of precipitation depositing as snow may decrease, and the typical timing of spring snowmelt could shift. Moreover, Markstrom and others (2012) predict a steady increase in minimum and maximum temperatures throughout the 21 st century over the range of greenhouse gas emission scenarios evaluated.

\section{Wetland Management on Federal Lands}

The USFWS typically manages wetland impoundments according to habitat objectives that are based on providing the life requisites of a specific suite of taxa, which often vary by season. For example, spring water levels in an impoundment may be increased to provide optimal nesting and roosting habitat for colonial-nesting waterbirds and lowered in the fall to provide foraging habitat for fall migrating shorebirds. Wetland managers also may use water-level manipulations or flushing to alleviate water-quality problems or alter vegetation communities. For example, wetland water levels may be lowered to encourage deflation of salts (removal by wind) from exposed sediments, or influxes of freshwater during floods may be used to flush accumulated salts. Similarly, undesirable monotypic stands of cattail (Typha sp.) can be diminished by increasing water levels for extended periods of time, or influxes of freshwater at specific times can reduce salinity levels and encourage germination of freshwater vegetation.

Projected climate-driven alterations to water availability may limit flexibility to achieve specific habitat objectives or require modifications to account for shifting climate patterns. For instance, changes in the timing or intensity of precipitation, snowmelt, or springtime river flows may constrain the ability to implement desired water-level manipulations, and higher temperatures and longer growing seasons could result in greater water losses through evapotranspiration, which could substantially alter the seasonal water balance of an impoundment. Various climate-related impacts that constrain a manager's ability to manipulate the water level of impoundments could result in changes to vegetative habitat conditions (plant community composition, structure, and distribution) and water chemistry. Increases or decreases in the amount of water delivered to a system may result in a shift of the ratio between open water, emergent vegetation, and mudflats; and concentrations of salts or harmful elements (for example, trace metals) can change drastically in response to dilution or evapoconcentration.

Historically, climate patterns in the northern Great Plains have alternated between wet and dry periods with no identifiable frequency of cycles, but droughts have persisted for longer periods in interior sections of the country than sections closer to the coast (Karl and Koscielny, 1982). As such, the USFWS has developed flexible management objectives to capitalize on this natural variation. For example, during dry periods wetland managers may reduce water levels to the greatest extent possible to encourage nutrient cycling and changes in plant community composition and structure. However, because of uncertainties pertaining to future climate trends and water supplies, current management objectives may have to be modified or new ones developed. Thus, wetland managers would benefit from a tool for assessing the effects of projected changes in climate and water availability on their ability to achieve current or alternative management objectives.

The primary purpose for modeling habitat characteristics of wetland impoundments, from a conservation manager's perspective, is to determine the most appropriate allocation of water resources based on biological goals, potential water availability, and climate conditions. The overarching goal is to provide habitat conditions that support and sustain target wildlife populations such as migratory waterbirds. For instance, many waterbirds exhibit optimal water depths for foraging, preferences for food resources that often vary seasonally, and require certain vegetation conditions (distribution, height, cover) to successfully complete critical life-history events such as breeding and migration (Swanson and others, 1974; Fredrickson, 1991; Skagen and Knopf, 1994; Colwell and Taft, 2000; Laubhan and others, 2006; Niemuth and others, 2006; 
Ma and others, 2010); all factors that can be manipulated through water management. Similarly, most aquatic plants and invertebrates, which provide critical food and habitat resources for waterbirds, are linked to optimal salinity levels or water depths (Stewart and Kantrud, 1972; Hammer and Heseltine, 1988; Baskin and Baskin, 1998; Laubhan and others, 2006; Gleason and others, 2009).

\section{Background and Previous Work}

A multitude of approaches have been applied to evaluate the effects of land use, climate, water availability, and water allocation to the water balance of wetlands, lakes, and drainage basins (Hamilton and others, 1989; Poiani and others, 1996; Kendy, 1999; Su and others, 2000; Vining, 2007; Markstrom and others, 2012; Nimick and others, 2011). This project required a model capable of simulating the water and salt budget of managed impoundments and that provides outputs that can be related to habitat quality. Examples of common models and tools that have been well-vetted and are readily available as software packages include the Precipitation-Runoff Modeling System (PRMS; Leavesley and others, 1983) and the Soil \& Water Assessment Tool (SWAT; Neitsch and others, 2011). However, use of these software-based models often requires specialized training or computer expertise, and they can be difficult to customize. Further, required data often are not readily available or must be manipulated prior to input.

No software packages were identified that provided the desired model outputs, so an existing model framework was simplified and developed in Microsoft Excel. The water and salinity balance (WSB) model developed for this study is based on a water and salt balance model for BNWR that was developed by Hamilton and others (1989) and later applied by Kendy (1999). The Hamilton and others (1989) model originally was written in standard FORTRAN and executed within a control system. In partnership with the USFWS, the Montana Department of Natural Resources and Conservation (MDNRC) converted this model for operation in Excel to conduct assessments of proposed management actions at BNWR (U.S. Fish and Wildlife Service, 2011). The WSB model framework presented in this report was modified from the MDNRC effort. The WSB model relies on widely available inputs, is easily adaptable, and provides desired outputs such as water level and specific conductance. Further, the WSB model is straightforward, transparent, and runs using standard spreadsheet software so it can easily be used as a tool to evaluate alternative management objectives for specific locations.

\section{Approach and Methods}

\section{Model Structure}

The Hamilton and others (1989) model incorporates water inputs from precipitation, numerous sources of surface water (for example, irrigation canal and surface runoff) and groundwater seeps. Water losses are attributed to evaporation, surface outflows, and seepage. The salt balance includes ions associated with the water sources, as well as salts that diffuse upward from the lake sediments and precipitate out of solution as water levels decline. This original model is very site specific, includes numerous variables that have to be estimated (for example, groundwater seepage and surface runoff), and is overly complex for some needs. Therefore, the Hamilton and others (1989) model was simplified to include only the primary sources and losses of water and salt, as well as variables that can be directly measured or predicted using currently available data. By simplifying this model, there is potential to lose some precision, but the inherent error was reduced by eliminating multiple factors (for example, groundwater interactions) that require estimation. Because the proposed model does consider the primary sources and losses, it should adequately capture overall trends required to evaluate management objectives and strategies. Moreover, the proposed model is easily modified to include additional variables when data are available.

The simple WSB model accounts for the primary sources and losses of water and salts associated with a given managed impoundment: direct precipitation, influx from rivers (regulated or unregulated), "other" surface-water influx (for example, inter-unit transfers), evapotranspiration (ET), and surface-water outflows. The combined overall WSB model is as follows:

$$
\begin{gathered}
\Delta V=P+S W I-E T-S W O \\
\Delta S=P_{S}+S W I_{S}-S W O_{S}
\end{gathered}
$$

where $\Delta V \quad$ is change in water volume $(V)$ stored in the impoundment,

$\Delta S \quad$ is change in mass of salts $(S)$ in water volume $(V)$

$P \quad$ is precipitation that falls directly on the inundated part of the impoundment,

$P_{S} \quad$ is mass of salts $(S)$ in precipitation $(P)$,

$S W I$ is water transferred into the impoundment through surface water input,

$S W I_{S} \quad$ is mass of salts $(S)$ in surface water inputs $(S W I)$,

ET is water evapotranspiration from the inundated part of the impoundment,

$S W O$ is water transferred out of the impoundment by surface-water outflow, and

$S W O_{S}$ is mass of salts $(S)$ in surface-water outflow $(S W O)$.

Specific conductance and surface-water (pool) elevation values are required to set initial impoundment conditions, and the WSB model requires a surface area-capacity-depth curve for the impoundment. Inputs and losses (water and salt) are calculated using precipitation, temperature, solar radiation, 
managed or unmanaged surface flows (rate and specific conductance of inflows/outflows), and management information (for example, elevation of water-control structures) at the desired temporal scale (for example, daily, monthly).

Once the initial conditions are input, the WSB model calculates the starting volume of water, surface areas (inundated and dry), mean depth for the impoundment, and mass of salts in the impoundment. The inundated surface area is defined as the part of the impoundment with standing water, and the dry surface area is the difference between the maximum area and the area that is inundated. The dry surface area could be mud flats or emergent or riparian vegetation. Volume, areas, and mean depth are based on the surface area-capacity-depth curve, and mass of salts is calculated by using a regression model to convert specific conductance (microsiemens per centimeter at 25 degress Celsius $[\mu \mathrm{S} / \mathrm{cm}]$ ) to total dissolved solids (TDS; milligrams per liter $[\mathrm{mg} / \mathrm{L}]$ ), which is adjusted for wetland volume. Models relating specific conductance and TDS (fig. 2) can be obtained from the literature or developed by collecting site-specific data. The mass of salts gained or lost from the impoundment is determined based on specific conductance of the inflows and outflows. Volume of water associated with direct precipitation and ET is determined by adjusting for the inundated area of the impoundment. Thereafter, the daily water balance for the impoundment is determined by adding the volume of water from direct precipitation and surface inflows and subtracting losses to ET and surface outflows.
When the calculated daily volume exceeds the maximum volume established by the height of the water-control structure, or when the water-control structure elevation is lowered, the excess volume of water (and associated salts) is treated as surface outflow that is completely removed at a daily time step. In reality, when an impoundment's volume exceeds its capacity, rate of water outflow is regulated by channel dimensions, topography, depth, and flow pathways. Thus, relations between pool elevation (stage) and discharge, when available, can greatly improve model performance by incorporating more accurate estimates of outflow rates (including interunit transfers between management units). These stage-discharge curves are less important for closed-basin type systems with limited outflow (for example, BNWR) but are critical for flowthrough type systems where an accurate accounting of both inflows and outflows is essential (for example, LLNWR and SLNWR).

The WSB model outputs include variables such as pool elevation, mean water depth, inundated and dry surface area, and specific conductance, which can all be used to assess habitat or management objectives. The WSB spreadsheet model is designed to run at a daily time step but can easily be modified to run at other time intervals. Further, the WSB model is designed to run for a single growing season but can be run over consecutive years by estimating winter precipitation, evaporation/sublimation, and inflows from spring snowmelt runoff.

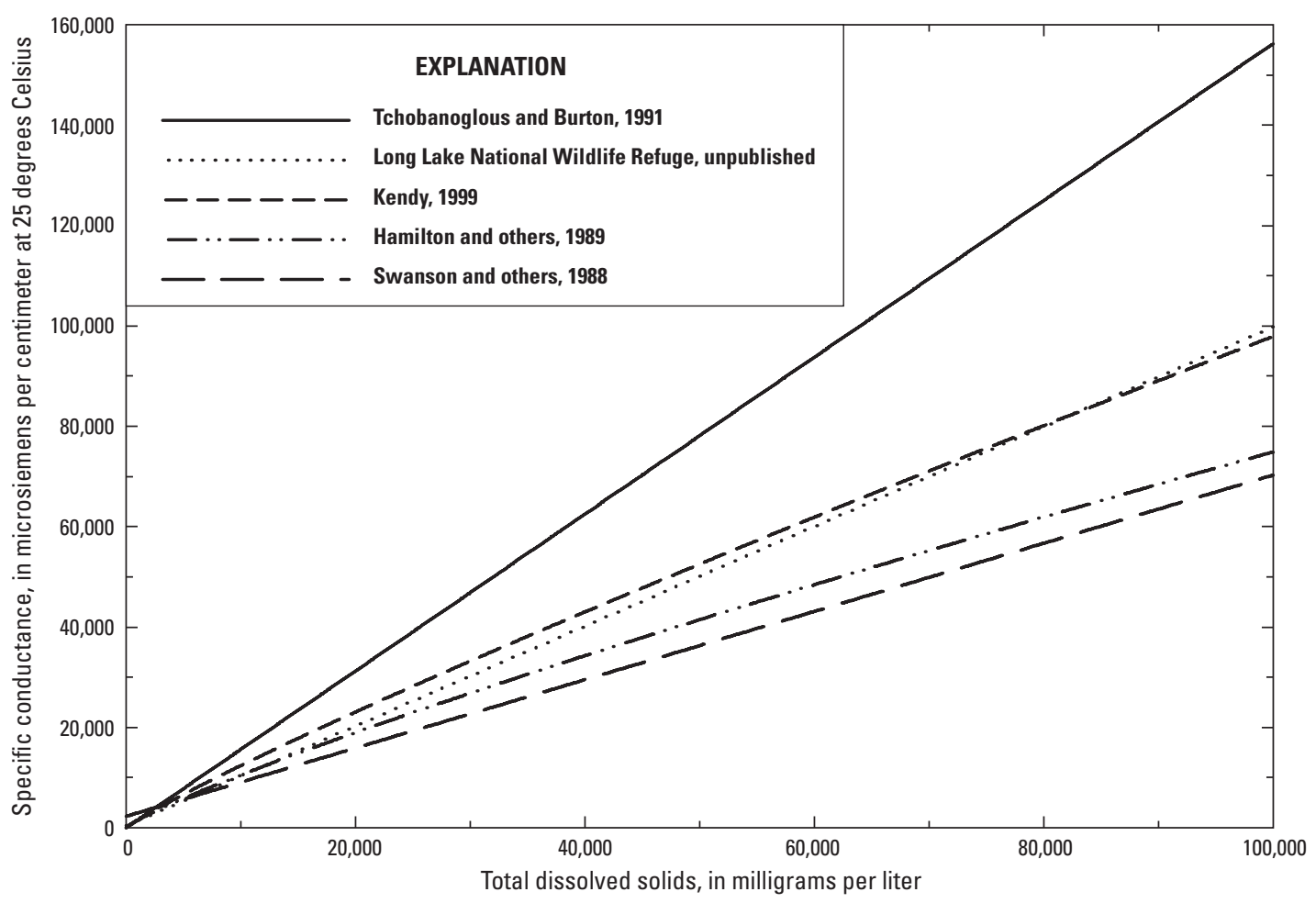

Figure 2. Relations between specific conductance and total dissolved solids. 
The WSB model determines daily outflow volume by calculating the difference between the modeled volume and the maximum volume based on the water-control structure elevation and incorporating any managed outflows by the use of canals or pumps. However, the WSB model structure allows for the incorporation of stage-discharge curves when available. The WSB model calculates potential ET using the Jensen-Haise equation (Jensen and Haise, 1963; McGuinness and Bordne, 1972; Rosenberry and others, 2004), which requires temperature and solar radiation as inputs. Pan evaporation (Hamilton and others, 1989; Kendy, 1999; Nimick and others, 2011) or other equations (Winter and Rosenberry, 1995; Rosenberry and others, 2004) can be easily substituted depending on the availability of input data. All WSB model variables and calculations are described in appendix 1 and general instructions for the WSB model are presented in appendix 2. An Excel version of the WSB spreadsheet model is available at $h t t p: / / p u b s . u s g s . g o v /$ sir/2013/5114/.

\section{Model Validation Methods and Study Sites}

To test and validate the WSB model, data were collected for three NWRs: BNWR, LLNWR, and SLNWR. All three NWRs were established during the dustbowl years of the 1930s with the goal of providing sustainable wetland habitats for migratory birds and other wildlife. The managed lakes of these refuges all rely, to varying degrees, on the timing and amount of water delivered from river systems to meet various water-quality, habitat, and management goals. Overviews are provided for each refuge in the following sections. Additional details about each NWR can be found in their respective Comprehensive Conservation Plans (CCP) (U.S. Fish and Wildlife Service, 2012a) and web sites (U.S. Fish and Wildlife Service, 2012b).

Model input and validation data were collected during the majority of the ice-free seasons of 2010 and 2011. Information for daily model inputs was collected where available on precipitation, temperature, solar radiation, surface-water inflows and outflows, and specific conductance of the inflow/ outflow waters. Surface area-capacity-depth curves also were obtained for each NWR. Additionally, each impoundment was instrumented with pressure transducers equipped with a conductivity sensor to collect continuous measurements of specific conductance and water depth, which was converted to pool elevation. Mean specific conductance and pool elevation were determined using daily values obtained from data loggers distributed around each impoundment. Data loggers were strategically distributed around each impoundment to capture potential spatial variation in specific conductance or pool elevation. Placement of the data loggers was based on previously collected data and knowledge of each impoundment, as well as accessibility. For BNWR, specific conductance and pool elevation represent a mean from three data loggers distributed around Lake Bowdoin during 2010 (May 14November 9) and 2011 (May 10-October 25). For SLNWR, specific conductance and pool elevation represent a mean from five (2010) and six (2011) data loggers distributed around Mud and Sand Lakes during 2010 (May 17-November 22) and 2011 (May 12-October 27), respectively. For LLNWR, specific conductance and pool elevation represent values from a single logger located near the outlet of Unit 1 during 2010 (April 23-November 19) and 2011 (May 11-October 26). Additional data were collected from the other management units of LLNWR, but they were not used in the WSB model validation.

The WSB model was adapted to each refuge and was run using starting values and inputs collected during data-logger deployment during 2010 and 2011. Results were compared to measured specific conductance and pool elevation to evaluate the WSB model performance for the dates that the data loggers were installed. Specifically, the average daily absolute difference between modeled and measured pool elevation and specific conductance was calculated, and the percentages of the modeled depth and measured specific conductance that these absolute differences represent were determined. For pool elevation, percentages were based on modeled data because a measured mean water depth for the impoundments was not available. The WSB model also provides estimates of mean depth and inundated and dry surface areas; these variables are calculated using the surface area-capacity-depth curves, and data to assess their precision were not collected because of time and budgetary constraints.

\section{Bowdoin National Wildlife Refuge}

BNWR is located in the Milk River Valley of north-central Montana (fig. 3). This area is a relatively arid (annual precipitation, 10-14 in.) region associated with downward trends in river flow over approximately the past 50 years (Anderson and Norton, 2007; Anderson and others, 2008). Managed wetland impoundments on BNWR rely heavily on water from the Milk River supplied through a manmade canal; thus, the refuge has an indirect connection to a river. BNWR was established in 1936 to provide habitat and refuge for migrating and nesting birds and other wildlife; today, it supports thousands of waterfowl, shorebirds, and colonial nesting waterbirds. The refuge has been widely recognized for its habitats and great value to migratory birds and has been included in the Western Hemisphere Shorebird Reserve Network and designated as a Globally Important Bird Area.

\section{Physical Setting}

BNWR covers approximately 15,500 acres and includes approximately 8,675 acres of freshwater and saline wetlands interspersed among mixed-grass prairie. Aquatic habitats on the refuge include five shallow lakes, the largest being the 5,459-acre Lake Bowdoin and the 1,200-acre Dry Lake (fig. 3). The refuge lakes and wetlands are divided by an array of dikes, roads, and a railroad bed; management and water transfers are accomplished through use of various 


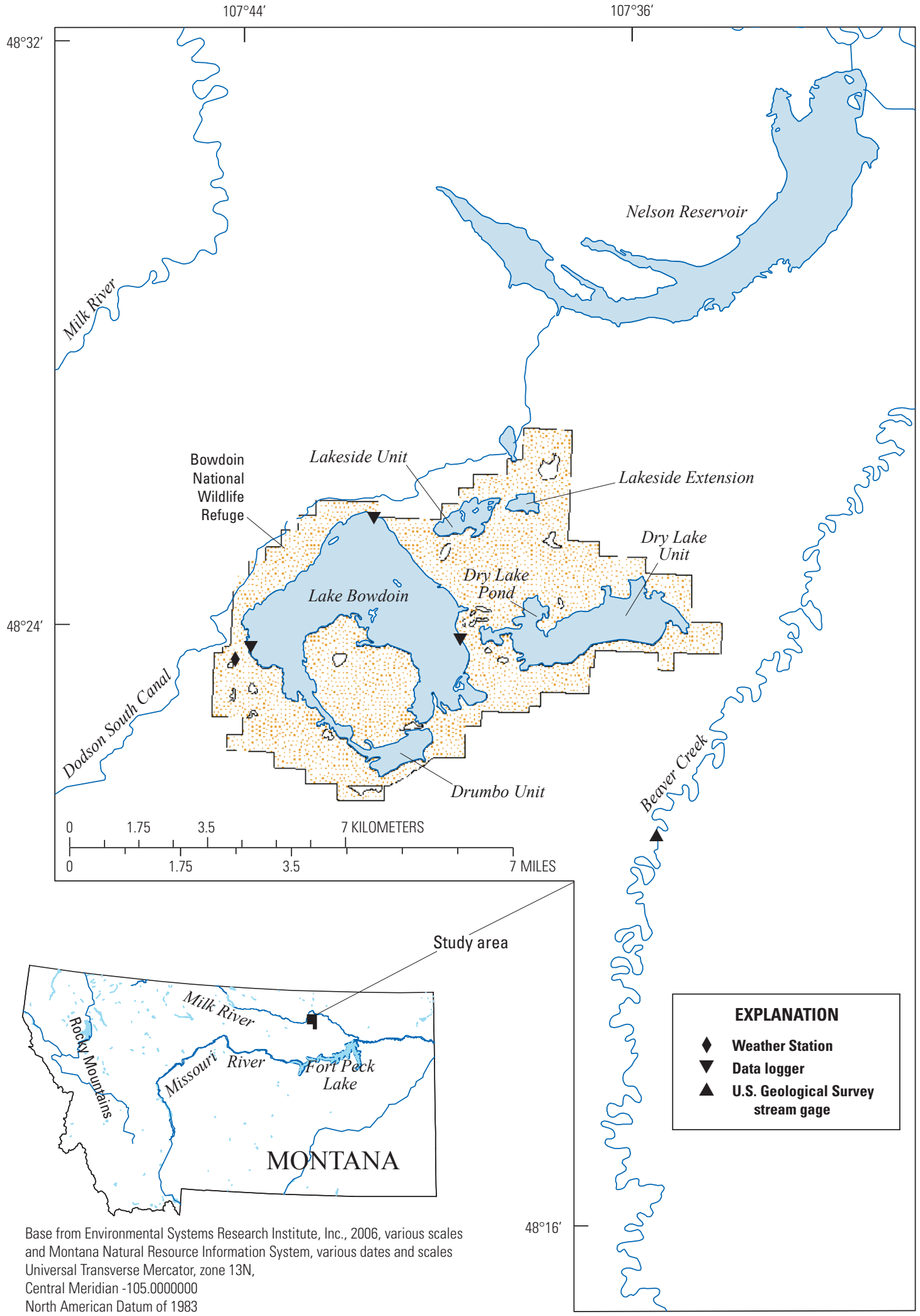

Figure 3. Location and primary management units of Bowdoin National Wildlife Refuge. 
water-control structures and ditches. Water levels fluctuate in response to water delivery, but average depths are less than 3.5 feet (ft).

\section{Water Resources}

Prior to European settlement, Lake Bowdoin likely functioned as a flowthrough wetland that released water to Beaver Creek. The refuge occupies a low point in the landscape, and with the additions of dikes and water-control structures, Lake Bowdoin currently functions as a closed-basin hydrologic sump with very limited surface outflow (for example, during Beaver Creek floods). The primary natural water sources for Lake Bowdoin are precipitation, runoff from the Black Coulee drainage (not shown on figure 3; enters the refuge near southwest arm of Lake Bowdoin), and episodic overbank flooding from neighboring Beaver Creek. Groundwater seeps also can contribute a relatively small amount of water to the lake (Kendy, 1999). These natural sources of water have been augmented by an annual allocation to the refuge of at least 3,500 acre-feet (acre-ft) from the Milk River through the Dodson South Canal, a component of the Bureau of Reclamation's Milk River Irrigation Project, and irrigation return flows from surrounding agricultural lands. The primary water loss is evaporation, which is more than double the average precipitation (greater than 24 and 12 in., respectively) on an annual basis (U.S. Fish and Wildlife Service, 2011). Water typically is not released downstream to Beaver Creek because of waterquality (salinity) concerns.

\section{Management and Environmental Concerns}

Historically, Lake Bowdoin presumably exhibited dynamic salinity levels that fluctuated in response to climatic cycles and floods. Early settlers greatly modified the landscape, shifting the lake primarily to a closed-basin system. Prior to establishment of BNWR, the lake was used by the Bureau of Reclamation to collect irrigation return flows and excess water from the Milk River project. After establishment of the refuge, the USFWS managed Lake Bowdoin to optimize habitat for waterfowl and other waterbirds, which resulted in the retention of all available water. The additions of more saline inflows, such as irrigation return flows, combined with management strategies to limit the amount of water exported from the lake and a negative precipitation-evaporation ratio led to the accumulation of salts and increased TDS concentrations over time.

During the 1970s, the USFWS recognized salinity was beginning to increase in Lake Bowdoin and Dry Lake, and since that time a primary focus of refuge staff is the management of salts. Currently, the main issues are deflation from Dry Lake that affects neighboring lands and elevated salinity levels in Lake Bowdoin. Specific concerns are the detrimental effects that elevated salinity levels can have on aquatic plants and invertebrates that are critical to waterfowl and other waterbirds (Gleason and others, 2009). Policies have been enacted to limit water (and salt) transfers from Lake Bowdoin to Dry Lake and to develop relatively permanent vegetative cover over the Dry Lake basin to alleviate some of the blowing salt problems. The water-quality issues of Lake Bowdoin have received considerable attention and study (Hamilton and others, 1989; Kendy, 1999), and management alternatives have been evaluated and approved to reduce and maintain salinity levels within an acceptable range (U.S. Fish and Wildlife Service, 2011).

\section{Model Inputs}

A majority of the data required to run and validate the WSB model was available for Lake Bowdoin. A stage-discharge curve was unavailable for Lake Bowdoin; but, because the Lake is essentially managed as a closed basin with no outflows, this lack of information did not affect model validation. Further, data were not available to account for water exchange with Beaver Creek during the 2011 flood described in the following paragraphs.

For 2010, hourly precipitation and temperature were obtained from a weather station located at the refuge, and solar radiation was obtained at 15 -minute intervals from the MESOWEST weather station (station MATM) located at Malta, Montana (not shown on fig. 3), approximately 7 miles (mi) to the west of the refuge (MESOWEST, 2012a). During 2011, hourly precipitation and temperature were obtained from a weather station located at the refuge; solar radiation was obtained at 15-minute intervals from the Malta weather station for the period of May 10-28 and at an hourly interval from the refuge weather station thereafter. Initial conditions for day one of the model runs were set using specific conductance and water levels measured in the field during data-logger deployment in the spring. Management information such as water-control structure elevations, amounts and specific conductance of inflows and outflows, and the surface area-capacity-depth curve were obtained from USFWS refuge staff. During 2010, the USFWS estimated that 3,485.7 acre-ft of water was delivered to Lake Bowdoin from August 23 to September 6 (for model validation inputs were calculated in equal intervals of 232.4 acre-ft/d); however, data from the data loggers indicated that water levels rose steadily from August 23 to September 11, so the canal inputs were adjusted accordingly by extending the daily inputs ( 232.4 acre-ft/d) for an additional 5 days. There were no managed inputs into the lake during 2011.

During 2011 there was significant spring flooding from Beaver Creek to Lake Bowdoin that resulted in elevated pool elevations and reduced specific conductance levels. The precise duration of the flooding and amount of water exchanged are unknown because a large proportion of the water exchange took place prior to installation of the data loggers on May 10. Once the data loggers were installed, a steady increase in water levels was observed until about mid-June; there were no documented deliveries from the canal during this period and the amount of water required to attain the observed pool levels greatly exceeded estimated inputs from direct precipitation. A comparison between Lake Bowdoin pool elevations and flows 
from Beaver Creek suggests that a large part of this water likely originated from Beaver Creek (fig. 4) because the peak flows correspond well to lake pool elevations. Field observations from U.S. Geological Survey (USGS) and USFWS personnel also indicate continued water exchange during this time period. Although it would have improved model performance, change in water volume was not calculated and included as a daily input because of the uncertainty involved. Further, not accounting for these ungaged inputs allowed for an assessment of model performance during an extreme flood year when exchanges between Lake Bowdoin and Beaver Creek typically are not quantified. No modifications were made to the WSB model, and contributions or losses associated with deflation, groundwater, or surface runoff from the surrounding grasslands were not considered.

\section{Long Lake National Wildlife Refuge}

LLNWR is located in south-central North Dakota (fig. 5). This area is a semiarid (annual precipitation, 15-17 in.) region associated with neutral river-flow trends over approximately the past 50 years (Anderson and Norton, 2007; Anderson and others, 2008). Long Lake, the primary wetland feature on the refuge, receives water from Long Lake Creek but also receives high spring runoff from local drainages. LLNWR was established in 1932 as a refuge for migratory birds and other wildlife; currently it provides critical resources for species such as cranes, geese, ducks, swans, and shorebirds. The refuge is a major staging area for the mid-continent sandhill crane (Grus canadensis) population, and threatened piping plovers (Charadrius melodus) and endangered whooping cranes (Grus americana) regularly utilize refuge habitats. The refuge's importance to the conservation of migratory birds has been recognized by its designation as a Globally Important Bird Area and a Western Hemisphere Shorebird Reserve Network site.

\section{Physical Setting}

LLNWR encompasses approximately 22,300 acres and includes nearly 16,000 acres of lakes and wetlands in a grassland and cropland dominated landscape. Long Lake, an approximately 16-mi long, 17,000-acre (including nonrefuge areas) shallow, alkaline lake is the predominant feature of the refuge (fig. 5). Long Lake is divided by dikes and watercontrol structures into four management units. The main body of Long Lake consists of Units 1, 2, and 3, which were formed by the construction of A, B, and C Dikes during the mid1930s. The fourth unit, Unit 2 marsh, is a roughly 800 -acre shallow wetland impoundment that was separated from Unit 2 in 1995 by construction of Unit 2 Marsh Dike and water-control structure (fig. 5). Refuge impoundments are all relatively

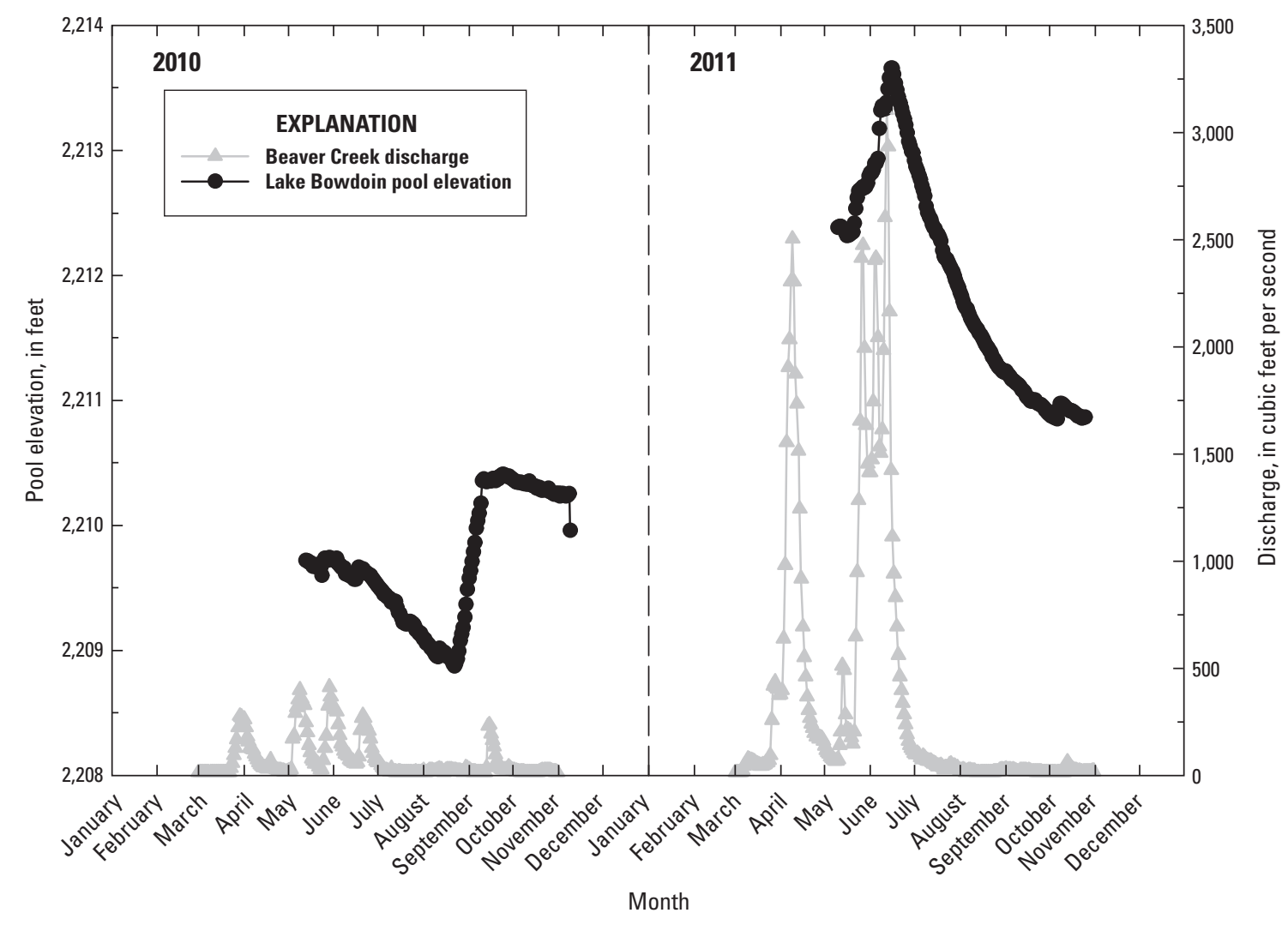

Figure 4. Lake Bowdoin pool elevations and stream discharge (U.S. Geological Survey streamgage 06166000 Beaver Creek below Guston Coulee near Saco, Montana) from Beaver Creek during 2010 and 2011. 


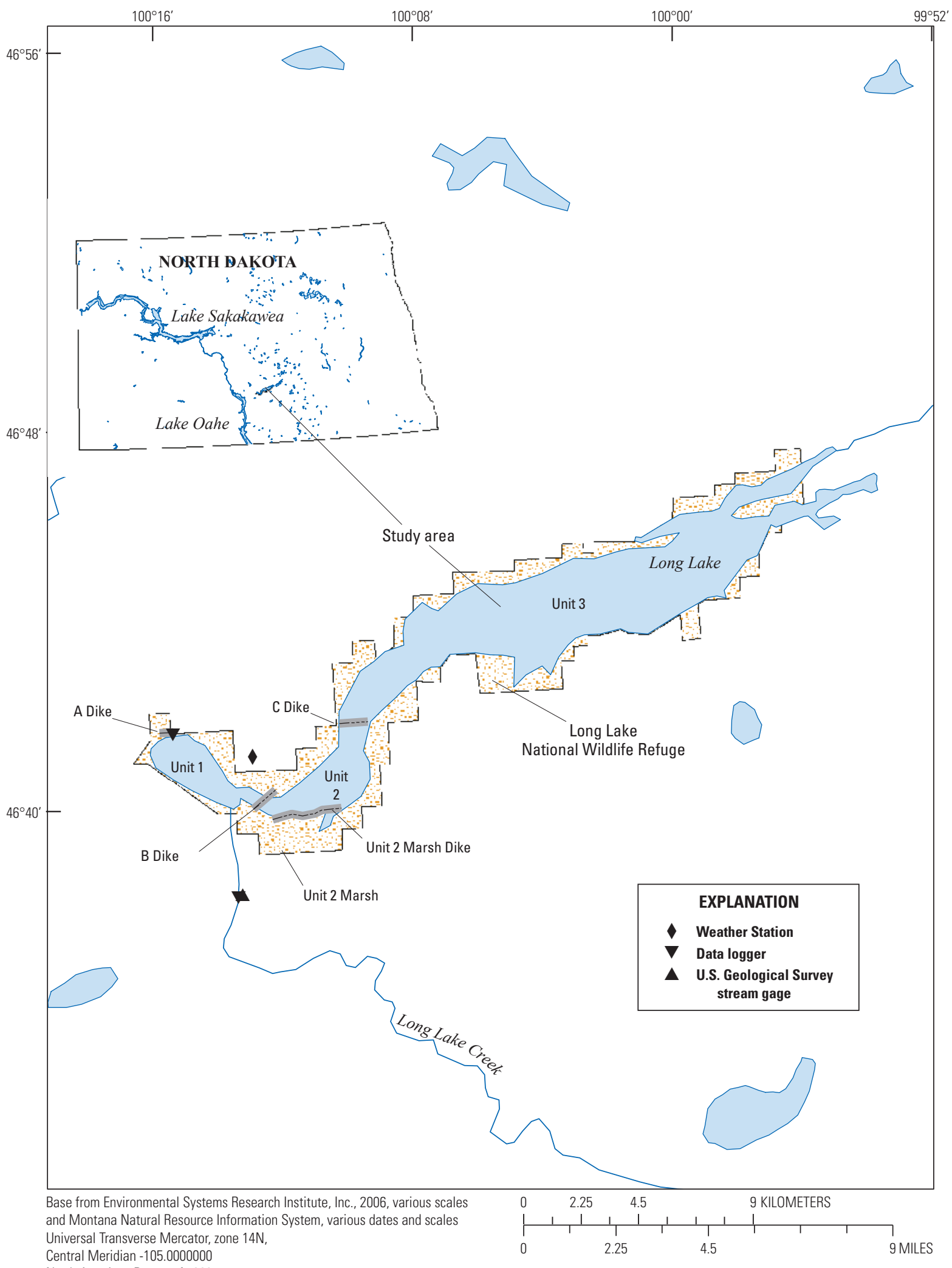

Central Meridian -105.0000000

Figure 5. Location and primary management units of Long Lake National Wildlife Refuge. 
shallow with maximum and average water depths less than $6.5 \mathrm{ft}$ and $3.5 \mathrm{ft}$, respectively.

\section{Water Resources}

The primary water sources for Long Lake are inflows from Long Lake Creek, runoff from the contributing drainages around the lake, and direct precipitation. In the semiarid climate of south-central North Dakota, average annual evaporation (33-40 in.) exceeds precipitation (16 in.), resulting in a negative ratio between precipitation and evaporation (U.S. Fish and Wildlife Service, 2006). Contributions from each water source have not been quantified; however, limited work performed by the USGS suggests that Long Lake Creek supplies approximately 68 percent of the water to Long Lake (U.S. Fish and Wildlife Service, 2006). Long Lake Creek flows directly into (and out of) Unit 1, which is separated from the other units by a dike and water-control structure; therefore, water levels in the other impoundments are highly dependent on the amount of spring runoff supplied by the contributing watersheds around the refuge. Prior to refuge establishment and the construction of water-control structures, Long Lake likely functioned as a closed-basin, alkaline system during average climatic years; water levels would have fluctuated dynamically in response to seasonal climatic events. During periods of high precipitation, lake levels would rise beyond the natural sill, and water would discharge into Long Lake Creek downstream from Unit 1 where water exits the refuge (Laubhan and others, 2006). Currently, water flows out of Unit 1 through the A Dike water-control structure and downstream through Long Lake Creek unless lake levels fall below the fixed-sill water-control structure at the lake outlet. Losses from Units 2 and 3 mainly are attributed to evapotranspiration as well as some outflow to Unit 1 (dependent on management). In general, direction of water flow in the refuge is from Unit 3 and Unit 2 into Unit 1 where it exits the refuge. Depending on annual and seasonal water inputs (primarily snowmelt runoff) and evapoconcentration, a significant salinity gradient can develop that increases from Unit 1 to Units 2 and 3.

\section{Management and Environmental Concerns}

Prior to the establishment of LLNWR, botulism outbreaks were common and likely resulted in the death of hundreds of thousands of birds during severe incidents. In fact, one of the primary reasons for constructing the dikes separating Long Lake into management units was to enhance the USFWS's ability to manipulate water levels to combat the outbreaks. However, the USFWS has limited ability to manipulate water levels because Unit 2, Unit 2 marsh, and Unit 3 are managed through adjustable water-control structures with a limited elevation range, and the water levels for Unit 1 are set by a fixed-sill structure. Water levels currently are managed primarily to reduce the frequency and magnitude of botulism outbreaks to the extent possible and to provide a mosaic of habitats, including emergent vegetation, mudflats, and open water, to support wetland-dependent birds.
A consequence of constructing the dikes at LLNWR is that the full pool elevation of the lake was raised more than $3 \mathrm{ft}$. While this increased water-holding capacity may have resulted in greater management flexibility, there may be unforeseen water-quality consequences associated with altered hydrology and prolonged periods of inundation. For example, there are concerns that salt concentrations have increased because of the interruption of periodic flushing events, and it has been suggested that various chemical constituents, such as trace metals, may accumulate and reach levels that are detrimental to biotic communities (Laubhan and others, 2006). As a result, the USFWS has recently implemented a monitoring program to identify potential water-quality (including salinity) issues and to broaden and enhance their management strategies.

\section{Model Inputs}

Only a part of the data required to run and validate the WSB model was initially available for LLNWR. The primary data gaps were the lack of stage-discharge curves to estimate flows from the refuge and exchanges among the management units within the refuge. Further, inputs to the refuge from the Long Lake Creek watershed were unknown because Long Lake Creek does not have an active USGS streamgage station. Inputs from the small, ungaged drainages immediately surrounding the refuge were also unknown. These local inflows can be significant, especially during spring snowmelt, and can account for a large part of the water inputs for Units 2 and 3 and Unit 2 marsh.

Once these data gaps were identified, additional data collection was initiated with the purpose of developing stage-discharge curves for Long Lake Creek and Unit 1 that could be used to estimate overall refuge inflows and outflows associated with Long Lake Creek. In cooperation with the USGS North Dakota Water Science Center, Acoustic Doppler Velocity Meters (ADVMs) were installed in two locations where water exits Unit 1 and flows out to Long Lake Creek. Data from the ADVMs were used to develop a stage-discharge curve for estimating outflow from Unit 1 . In addition, limited historic data from the inactive USGS streamgage station (USGS streamgage 06349215 Long Lake Creek above Long Lake near Moffit, N. Dak.) located on Long Lake Creek and streamflow data from an ongoing project with the North Dakota Department of Health were used to develop a stage-discharge curve for Long Lake Creek. This curve was used in conjunction with elevations from the data logger to estimate inflows to the refuge from Long Lake Creek. Accurate estimations of the local inflows to Units 2 and 3 and Unit 2 marsh would require intensive, long-term study. Therefore, this initial WSB model validation was limited to Unit 1.

For 2010 and 2011, hourly data on precipitation, temperature, and solar radiation were obtained from the MESOWEST weather station (station TS633) located at the refuge (MESOWEST, 2012b). Specific conductance for inflows was obtained from the Long Lake Creek data logger. Initial 
conditions for day one of the model runs were set using specific conductance and water levels measured in the field during data-logger deployment in the spring. Management information such as water-control structure elevations and the surface area-capacity-depth curves were obtained from USFWS refuge staff.

The outlet for Unit 1 consists of a fixed-sill (nonadjustable) box culvert. The WSB model was modified so that all outflow was calculated using the stage-discharge curve developed for Unit 1; if pool elevation drops below the fixed-sill elevation then outflow equals zero. The WSB model estimates did not include contributions or losses associated with groundwater, surface runoff from the surrounding uplands, or bidirectional flows through the water-control structure located between Unit 1 and Unit 2.

\section{Sand Lake National Wildlife Refuge}

SLNWR is located in northeastern South Dakota (fig. 6). This area receives more precipitation (annual precipitation, 18-20 in.) than the Bowdoin and Long Lake NWRs and is associated with a river that has exhibited upward river-flow trends over approximately the past 50 years (Anderson and Norton, 2007; Anderson and others, 2008). SLNWR is situated directly on the James River where two dams form relatively large, shallow lakes. SLNWR was established in 1935 as a breeding ground and refuge for migratory birds and other wildlife. Currently (2013), the NWR supports snow geese (Chen caerulescens) and other waterfowl, shorebirds, white pelicans (Pelecanus erythrorhynchos), and colonial nesting birds; the refuge also is known for the world's largest nesting colony of Franklin's gulls (Larus pipixcan). Sand Lake has been cited as a leading destination for birding and designated a Wetland of International Importance and a Globally Important Bird Area.

\section{Physical Setting}

SLNWR encompasses approximately 21,500 acres, including roughly 11,450 acres of wetland habitats. The refuge, situated directly on the James River, consists of two main water bodies that were created by dams during the 1930s: Mud Lake and Sand Lake (fig. 6). Mud and Sand Lakes cover up to 5,300 and 6,100 acres, respectively, and are separated by an earthen dam and water-control structure. The James River flows from north to south, and Mud Lake is upstream (north) from Sand Lake. Additionally, Sand Lake is divided on the north end by a highway with bridges and watercontrol structures that allow water to flow downstream. Both impoundments are relatively shallow, with depths averaging approximately $1.50 \mathrm{ft}$ in Mud Lake and $2.75 \mathrm{ft}$ in Sand Lake during average precipitation years and under current management; maximum pool depths approach $6 \mathrm{ft}$. Flows through the SLNWR are rather slow and barely perceptible.

\section{Water Resources}

The primary water sources for Mud and Sand Lakes are inflows from the James River and direct precipitation. Flows of the James River vary greatly with climate (fig. 7) and water levels of Mud and Sand Lakes are highly dependent on spring river flows during normal precipitation years. Mud and Sand Lakes are considered a flow-through system even though water is stored within the refuge impoundments and flow through the system is slow.

\section{Management and Environmental Concerns}

The standard water-management strategy is to fill Mud and Sand Lakes to capacity during the spring and maintain full-pool levels through mid-August; levels are dropped in the fall to protect infrastructure from ice damage after freezeup. Following extended periods of high water (for example, at or above full-pool levels), growing-season drawdowns are implemented when conditions permit to facilitate reestablishment of emergent vegetation. However, management flexibility is limited by infrastructure and flows of the James River.

The primary goal of the refuge staff is to manage Mud and Sand Lakes to provide wetland habitats favored by overwater-nesting birds and waterfowl. Specific objectives include managing the lower part of Mud Lake for 30-50 percent emergent vegetation and the northern end of Sand lake for 30-60 percent emergent vegetation; water depths ranging from approximately 8-20 in. are desirable during spring and summer for both impoundments. Managing wetlands in this manner provides open water in the deeper parts of the lakes and shallow water dominated by emergent vegetation along lake fringes. This range of habitats supports the overwater-nesting birds and waterfowl as well as other wetland-dependent species that prefer the shallow-water habitats.

Because SLNWR is a flow-through system, refuge impoundments do not have the same salinity and water-quality problems that characterize many of the refuges in the western part of the region; however, there are concerns over sedimentation of the Mud Lake impoundment (Gleason and others, 2003). The primary management concern for refuge staff is being able to manage water levels at the desired level, especially during high-flow years when habitats are flooded and the dams and water-control structures are overtopped. Consecutive years of high water can result in the loss of emergent vegetation habitats that are critical for a large proportion of the refuge's key bird species.

\section{Model Inputs}

A majority of the data required to run and validate the WSB model were available for SLNWR. Because SLNWR is a flow-through refuge situated directly on the river, the WSB model required modification to calculate outflows. The primary data gap was the lack of stage-discharge curves for 


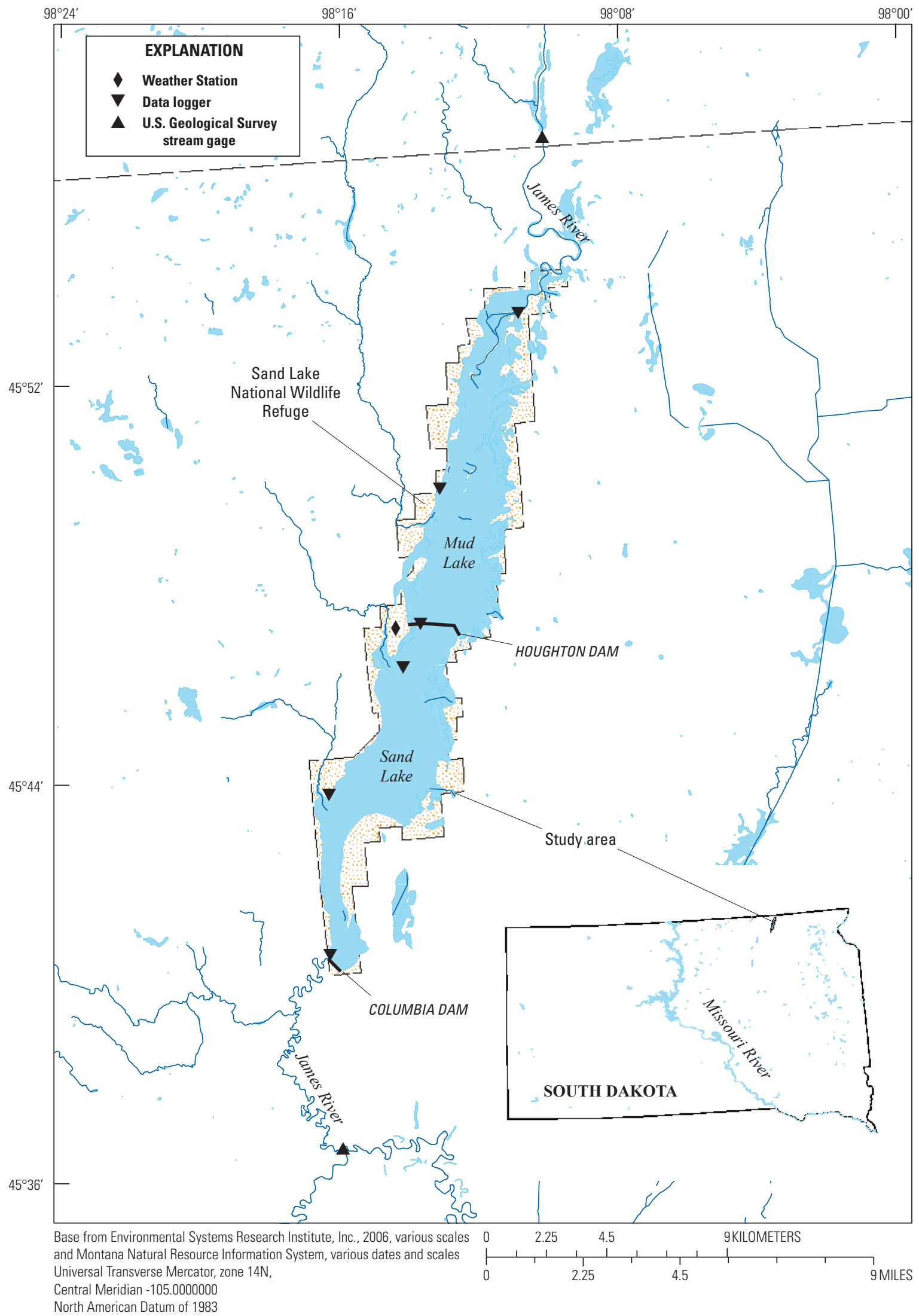

Figure 6. Location and primary management units of Sand Lake National Wildlife Refuge. 


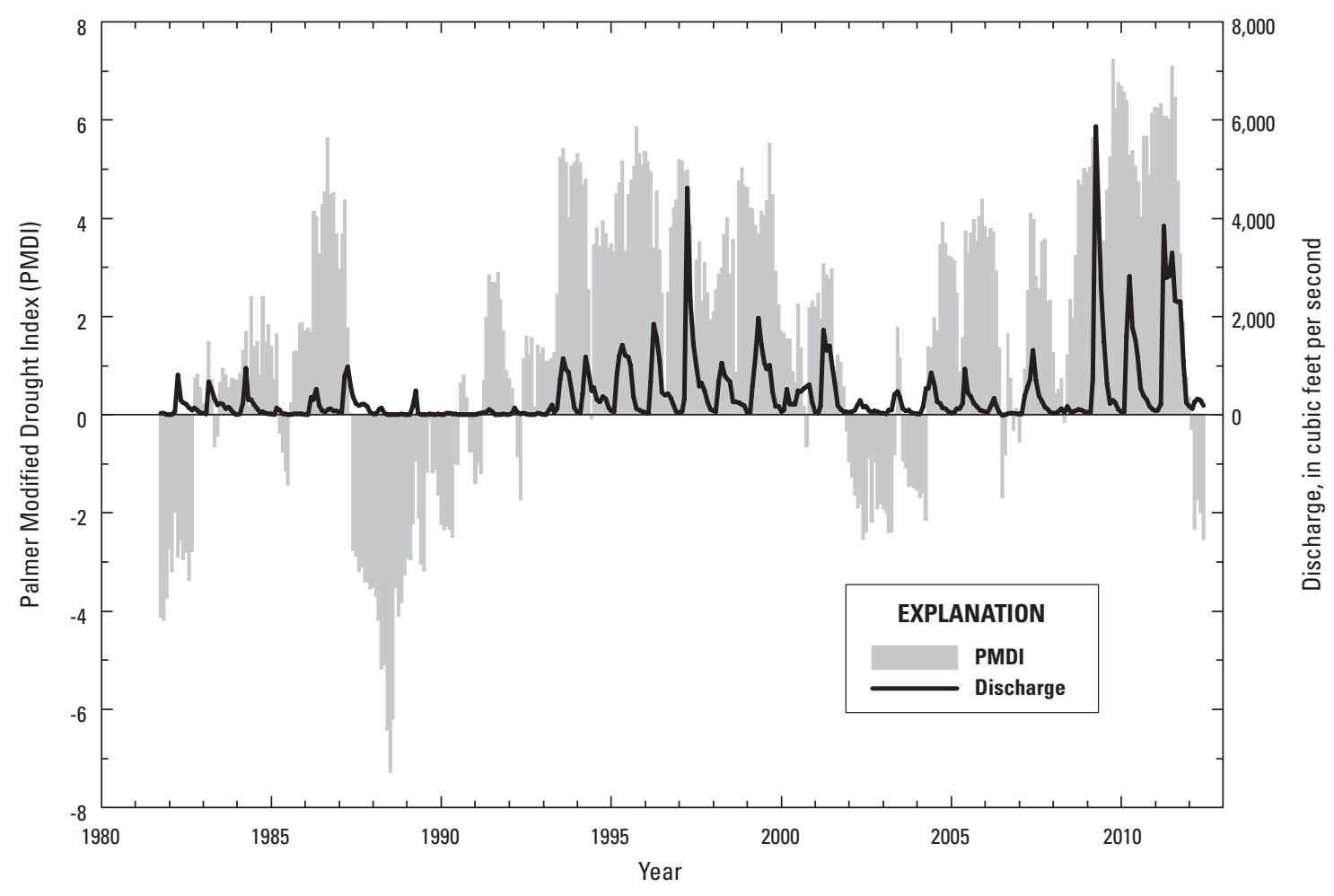

Figure 7. Palmer Modified Drought Index values for northeastern South Dakota and discharge for the James River (U.S. Geological Survey streamgage 06470878 at the North Dakota/South Dakota border) from October 1, 1981, to June 1, 2012.

estimating flows from Mud Lake to Sand Lake and from Sand Lake to the James River (fig. 6). Additionally, the watercontrol structures and dikes that separate Mud and Sand Lakes were overtopped for a part of 2010 and 2011 because of extremely high river flows (fig. 7). Therefore, even if the appropriate stage-discharge and water-control structure elevation information were available estimating flows would have been difficult because discharge exceeded the capacity of the water-control structures for extended periods of time.

Because of these limitations, each impoundment could not be modeled independently. However, the combined water balance of both impoundments was modeled by calculating combined areas and volumes. To apply the WSB model in this manner, a surface area-capacity-depth relation was developed for both units by summing areas and volumes from the individual curves for each impoundment using pool elevation. Further, a rough stage-discharge curve was developed based on historic pool elevations and stream-discharge rates from the USGS streamgage located approximately $3.5 \mathrm{mi}$ downstream from the refuge (USGS streamgage 06471000 James River at Columbia, S. Dak.); this curve was used to calculate discharge from the refuge to the James River. For each date that pool elevations and daily discharge (1,397 observations from 1980 to 2011) were available for both impoundments, a mean pool elevation for the refuge (mean of Mud and Sand Lake elevations) was calculated, and this value was related to daily discharge. Mean discharge rates were calculated based on 0.5-ft intervals of pool elevation and a Microsoft Excel lookup function was created that estimates daily outflow based on elevation. Data were not available to account for water-control structure elevation when developing this curve; thus, discharge was predicted based solely on pool elevation. There is flow from a small local drainage area to the James River that is located between the refuge and the USGS streamgage located approximately $3.5 \mathrm{mi}$ downstream of the refuge, and the relative volume of this contribution varies seasonally because of precipitation events. Therefore, using this streamgage to develop the rough stage-discharge curve could result in slight overestimates of discharge from the refuge.

For 2010, hourly precipitation and temperature data were obtained for the period between May 17 and July 22 from the National Oceanic and Atmospheric Administration (NOAA) weather station located approximately $3.5 \mathrm{mi}$ to the south of the refuge at Columbia, S. Dak. (not shown on fig. 6) (station Columbia $8 \mathrm{~N}$; National Oceanic and Atmospheric Administration, 2012). Daily solar radiation for the same period was obtained from the North Dakota Agricultural Weather Network weather station located approximately $25 \mathrm{mi}$ to the east at Britton (not shown on fig. 6), South Dakota (North Dakota Agricultural Weather Network, 2012). For the remainder of 2010 and all of 2011, hourly weather data were obtained from a weather station located at the refuge. Inflows to the refuge from the James River were estimated using daily discharge data from the USGS streamgage located approximately $3.5 \mathrm{mi}$ above the refuge (USGS streamgage 06470878 James River at the North Dakota/South Dakota border) and specific 
conductance for inflows was obtained from a data logger located where the James River enters Mud Lake. Initial conditions for day one of the model runs were set using specific conductance and water levels measured in the field during data-logger deployment in the spring. Information on management, such as historic pool elevations and surface areacapacity-depth curves was obtained from USFWS refuge staff. The WSB model was modified so that estimates of outflow were calculated using the stage-discharge curve, regardless of water-control structure elevation. Contributions or losses associated with groundwater or surface runoff from the surrounding uplands were not considered.

\section{Model Application}

\section{Overview}

An overarching goal of USFWS staff at BNWR is to provide and manage wetland habitats for breeding and migratory birds and other wildlife. One of the primary management concerns is the long-term accumulation of salts in Lake Bowdoin and the resulting increase in salinity that, if not controlled, will eventually diminish habitat quality for waterbirds. Evapoconcentration of salts over time can negatively affect aquatic communities such as plants and invertebrates (Gleason and others, 2009), and elevated salinity can limit management options because regulations prohibit downstream releases of water that are of lower quality than the receiving waters (for example, discharge of saline water from the refuge to Beaver Creek). Under current management guidelines there are no regulated releases of water from Lake Bowdoin, and the primary mechanisms for salt removal are deflation and infrequent flushing events associated with Beaver Creek floods; thus, salts from Dodson South Canal and other inflows generally accumulate over time.

During development of the CCP (U.S. Fish and Wildlife Service, 2011), USFWS personnel evaluated five scenarios for managing or removing salts in Lake Bowdoin: (1) current management, (2) evaporation ponds and removal of saline residue, (3) natural flushing by Beaver Creek, (4) underground injection well and natural flushing by Beaver Creek, and (5) pumping to the Milk River. Evaluations of each option were supported through assessments of the water and salt balance of Lake Bowdoin, and their primary purpose was to identify the best alternative for removing salts and maintaining desired salinity levels. Based on these evaluations, the fourth scenario was proposed as the best option on the basis of efficacy and cost.

For this study, the WSB model is used in a similar manner to assess effects to Lake Bowdoin associated with a future climate scenario, alternative management actions, and natural flooding events. The objective was not to duplicate the work already performed by the USFWS but to demonstrate the utility of the WSB model for simulating habitat characteristics and evaluating climatic shifts and alternative management objectives. Hence, simulations do not represent actual conditions or proposed management strategies, but show how the
WSB model could be used to evaluate forecasted climatic conditions and management alternatives.

The WSB model was demonstrated using Lake Bowdoin for a number of reasons. Lake Bowdoin is located in a semiarid region where salinity problems are common among managed wetlands, and there are ample data available because the lake has a long history of monitoring and scientific study. The refuge is essentially a terminal, closed-basin system with regulated canal inputs as the primary water source; thus, uncertainty associated with modeling watershed-level processes such as streamflow was reduced. Further, even though salts continue to accumulate in refuge wetlands, specific conductance oscillates over time in response to water levels (concentration and dilution) that can be regulated by management, although control often is limited by the annual allocation of water received from the Milk River Project and periodic Beaver Creek floods. As an example, figure 8 shows drastic reduction in Lake Bowdoin specific conductance levels associated with the two most recent Beaver Creek floods (circa 1986 and 2011). This figure also shows a moderate relation between the occurrence of floods and the Palmer Drought Index (surrogate for climate), and demonstrates that conditions similar to those during flood years have occurred numerous times over the past century. Therefore, it is important for managers of BNWR to have the ability to model habitat conditions while considering potential changes to factors that affect the lake's water balance, such as managed inflows, climate, and floods. Lastly, high-resolution climate projections (see "Simulated Future Climate Inputs" section) for the refuge were available.

Considering the observed and projected trends of accumulating salts and temporal variation in specific conductance levels, coupled with projected climate scenarios (Karl and others, 2009; U.S. Fish and Wildlife Service, 2011), logical management questions are "what will Lake Bowdoin water depths and specific conductance levels look like under a potential future climate, what effects could various management actions (for example, altered canal inputs) have on future habitat conditions, and what effects could a change in the frequency of Beaver Creek floods have on salinity?"

The WSB model was used in conjunction with simulated climate data to evaluate effects of climate, management scenarios (altered canal inflows), and the importance of Beaver Creek floods on the future water and salt balance and habitat characteristics of Lake Bowdoin. Specifically, specific conductance, mean water depth, and inundated and dry surface areas were simulated over a 50 -year period to address the questions posed above. The primary goal of this exercise was to simulate abiotic habitat conditions and to identify potential effects to biotic communities. Simulations such as these will allow wetland managers to evaluate current or proposed management objectives and strategies and identify where alternatives should be developed to address potential shifts in climate and water availability. A secondary goal was to demonstrate the flexibility of the WSB model for assessing habitat conditions in response to changes in climate, management, or water availability. 


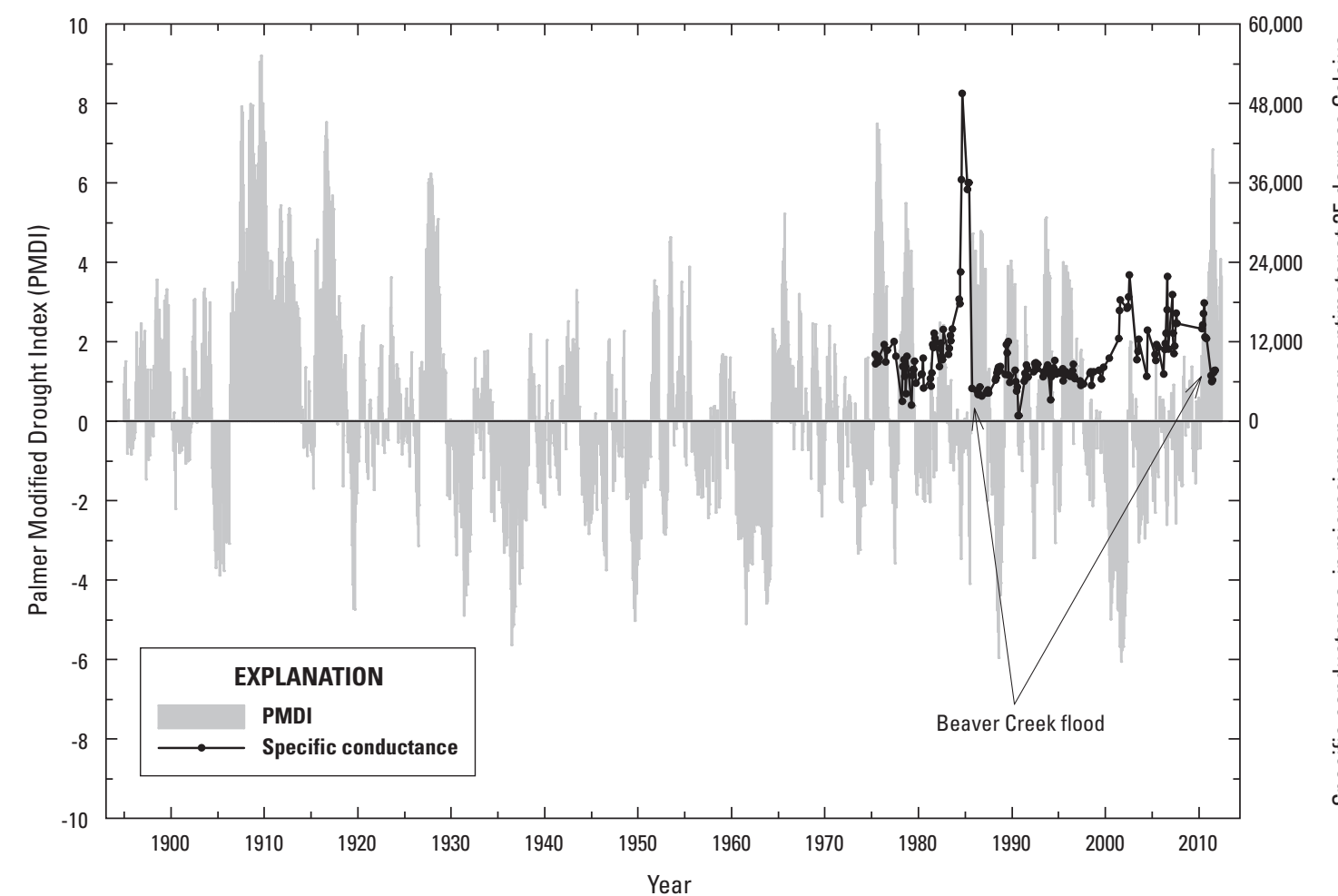

Figure 8. Palmer Modified Drought Index values (1895-2012) for north-central Montana and mean monthly specific conductance (1975-2011) for Lake Bowdoin. Arrows approximate the two most recent Beaver Creek flooding events (circa 1986, 2011).

\section{Methods}

\section{Model Simulation}

Six 50-year model simulations were performed at a daily time step during the approximate ice-free period (AprilNovember) for Lake Bowdoin. The first simulation was intended to assess any effects associated with projected climate change; therefore, canal deliveries were based on historical averages and held constant among years. The second and third simulations were intended to depict changes associated with altered canal deliveries. For the second simulation, canal deliveries were reduced by 20 percent to assess the effect of reduced salt and water inputs. Conversely, for the third simulation, deliveries were increased by 20 percent to assess effects associated with increased salts and dilution through greater canal deliveries. A second set of three simulations, similar to those described above, were performed to simulate the long-term effects of periodic Beaver Creek floods on salinity concentrations. Various assumptions, described in the following paragraph, were made in order to run the WSB model across years; therefore, single-season simulations also were performed using 50 -year averages from the climate simulation to remove the inherent errors associated with these assumptions.

For the first set of simulations, water balance information for the winter months (December-March) was estimated based on the historic average, and this value was used to set initial conditions at the beginning of the active model period (April 1) of each year (see "Model Inputs" section). For example, the long-term average snowmelt-runoff volume was included on the first active model day of each year. Initial conditions (specific conductance, pool elevation) for the first year of all simulations were arbitrarily specified as a mean of the observed values from August 2011. The first set of three simulations did not include any inputs from Beaver Creek (periodic floods). The second set of three simulations included substantial Beaver Creek floods at a 20-year frequency of occurrence. It is difficult to predict the timing or magnitude of these flood events, but frequency and exchange volume were approximated based on existing data and past events (fig. 8). For all simulations, the lake was assumed to be a terminal, closed-basin system by setting the water-control structure elevation at the maximum of $2,214 \mathrm{ft}$.

\section{Model Inputs}

Daily temperature and precipitation values were obtained from a simulation of the A2 emissions scenario (see "Simulated Future Climate Inputs" section). Daily evapotranspiration was estimated using the Jensen-Haise model along with daily temperature and solar radiation; daily solar radiation was based on a 10-year daily average (2000-10) for Malta, Mont. Temperature and precipitation were the only daily input variables that differed among years, all other variables remained unchanged. The timing and amount of water deliveries from the Dodson South Canal were calculated based on estimated deliveries from 1988 to 2008; daily values were calculated by dividing the mean monthly value by the number of days in the month. 
Specific conductance of the canal deliveries was based on existing data (mean from 1987 to 2007) and set at $600 \mu \mathrm{S} / \mathrm{cm}$.

Simulations are constrained by uncertainties associated with the choice of starting conditions, annual canal deliveries (timing and amount), estimates of ET and spring runoff (including floods), and precipitation and temperature from the modeled climate data. The WSB model was designed to run for a single ice-free season. Multiyear runs are difficult to implement because snowpack, timing and volume of spring runoff, and wintertime evaporative losses are extremely variable and difficult to accurately estimate. Consequently, contributions and losses were estimated over the winter months to conduct the 50-year simulations, and this information was used to set initial conditions on April 1 of each year. Losses to sublimation were applied at a rate of 1 inch per month (Kendy, 1999). To account for inputs from winter precipitation and spring snowmelt, mean change in surface-water elevation was determined from fall to spring over a 17-year period (fall of 1990-spring of 2007); volume of water required for this change was calculated using the surface area-capacity-depth curve. Based on these calculations, 1,105 acre-ft of water (specific conductance $=100 \mu \mathrm{S} / \mathrm{cm})$ were added on the first model day (April 1) of each year to account for winter precipitation and spring runoff. For the simulations that included Beaver Creek floods, water volume of Lake Bowdoin before and after the 2011 flood was approximated using measured pool elevation and the surface area-capacity-depth curve. The change in volume, which was approximately 13,760 acre-ft, was attributed to flooding from Beaver Creek; hence, this volume was applied on the first model day (April 1) for each of the 2 years where floods were simulated.

\section{Simulated Future Climate Inputs}

A regional climate simulation was performed for water years 2001-50 (Norton and Stamm, 2012); data from the two grid points that overlay BNWR were used for this modeling exercise. Climate output is from the Weather Research and Forecasting (WRF) model (Skamarock and others, 2008), which is a dynamical, high-resolution model. Initial and boundary condition data were from the Community Climate Systems Model (version 3.0) simulation of the A2 emissions scenario (Nakićenović and Swart, 2000). Overall, the 50-year simulation predicts a slight upward trend in mean annual and seasonal (April-November simulation period) temperature. This trend exceeds the recent 10-year (2001-11) annual average of $43.7^{\circ} \mathrm{F}$ for Malta, Mont., in most instances (fig. $9 A$.). Simulated annual and seasonal precipitation, however, is highly variable with no obvious trends (fig. $9 B$ ). Simulated annual precipitation exceeds the area's 12 -in. annual average (U.S. Fish and Wildlife Service, 2011) in greater than approximately 80 percent of the simulation years. On the basis of this climate simulation, there is potential for higher rates of water loss through ET because of higher temperatures, and greater than average water inputs through precipitation for a great majority of the simulation years.
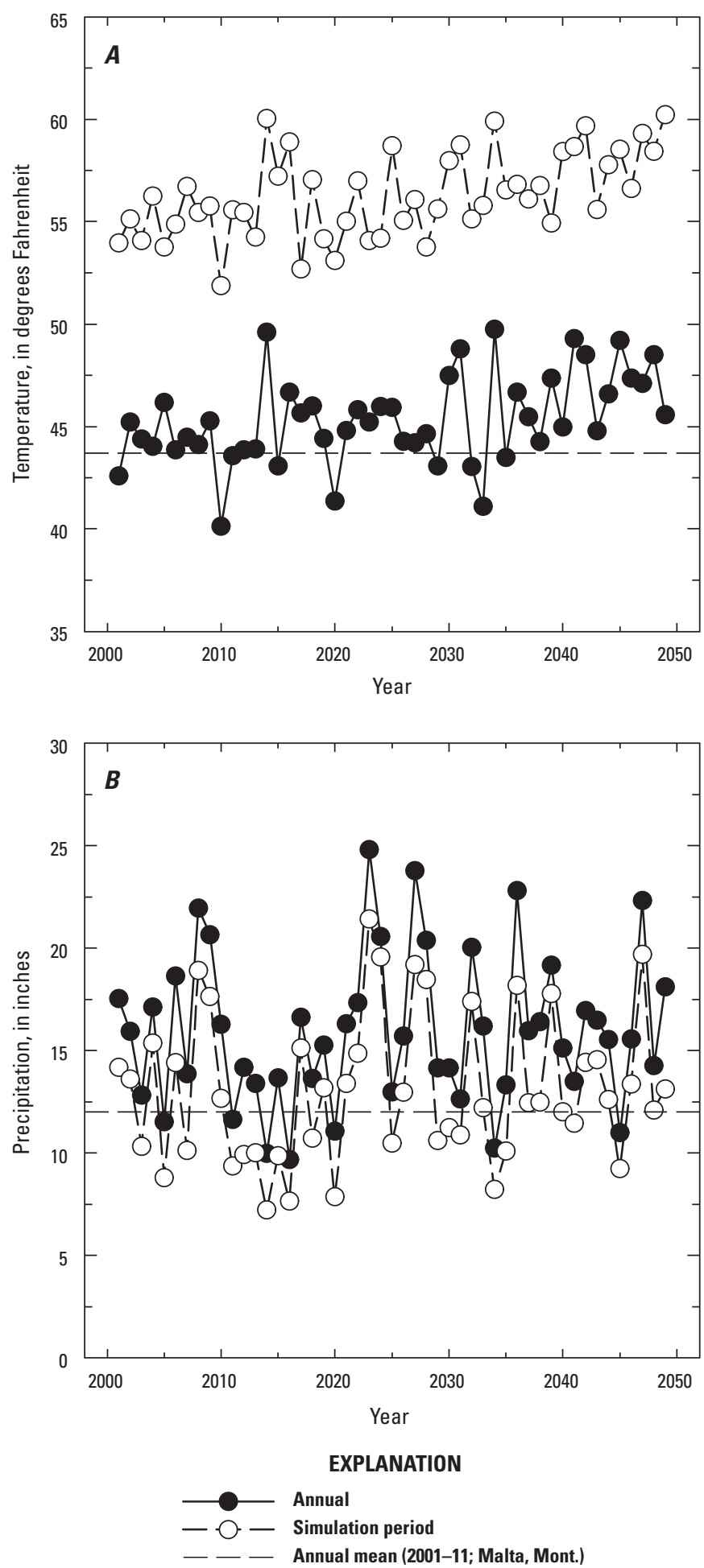

Figure 9. Outputs from the Weather Research and Forecasting (WRF) model simulation. $A$, Mean temperature for the entire calendar year (annual) and for the April to November time period (simulation period) used in the Lake Bowdoin simulation. $B$, Total precipitation for the entire calendar year (annual) and for the April to November time period (simulation period) used in the Lake Bowdoin simulation. 


\section{Validation and Application of the Water and Salt Balance Model}

\section{Results of Model Validation}

\section{Bowdoin National Wildlife Refuge}

In general, the WSB model produced temporal patterns and trends of pool elevation and specific conductance that were similar to measured values (fig. 10, table 1). The mean daily absolute differences between modeled and measured pool elevation were $0.06 \mathrm{ft}$ for 2010 and $0.38 \mathrm{ft}$ for 2011 . These differences equated to approximately 1.8 percent and 7.8 percent of the mean modeled water depths for 2010 and 2011, respectively. Mean daily absolute differences between modeled and measured specific conductance levels were $415.9 \mu \mathrm{S} / \mathrm{cm}$ (2.9 percent of observed mean) and $936.2 \mu \mathrm{S} / \mathrm{cm}$ (12.1 percent of observed mean) for 2010 and 2011, respectively. The WSB model consistently predicted higher specific conductance levels and underpredicted peak pool elevations during 2011. These discrepancies likely were a result of significant inputs of freshwater from the 2011 Beaver Creek flood (fig. 4) that resulted in higher observed water levels and lower observed specific conductance values when compared to the modeled values. The model also provided estimates of mean water depth and surface areas (fig. 11) that are calculated using the surface area-capacity-depth curve; the precision of these estimates was not assessed.

Overall, WSB model performance was superior during 2010 when there was no unmanaged mixing with Beaver Creek; however, despite the fact that water inputs from the 2011 spring flooding were not included, the model still reflected pool elevations and specific conductance levels adequate for management (fig. 10). Disregarding the obvious unmanaged inputs during the spring of 2011, the WSB model predicted a lower rate of decline in pool elevation after midJune when compared to the observed trend. This observation suggests there were unmanaged (ungaged) outflows because of high water levels or actual ET was greater than predicted. Because the WSB model (estimated ET) seemed to perform well throughout 2010, the divergence between the modeled and measured rate of decline during 2011 was likely due to unmanaged outflows not accounted for in the model. However, the possibility that a part of this discrepancy is due to differences between modeled and actual ET cannot be discounted.

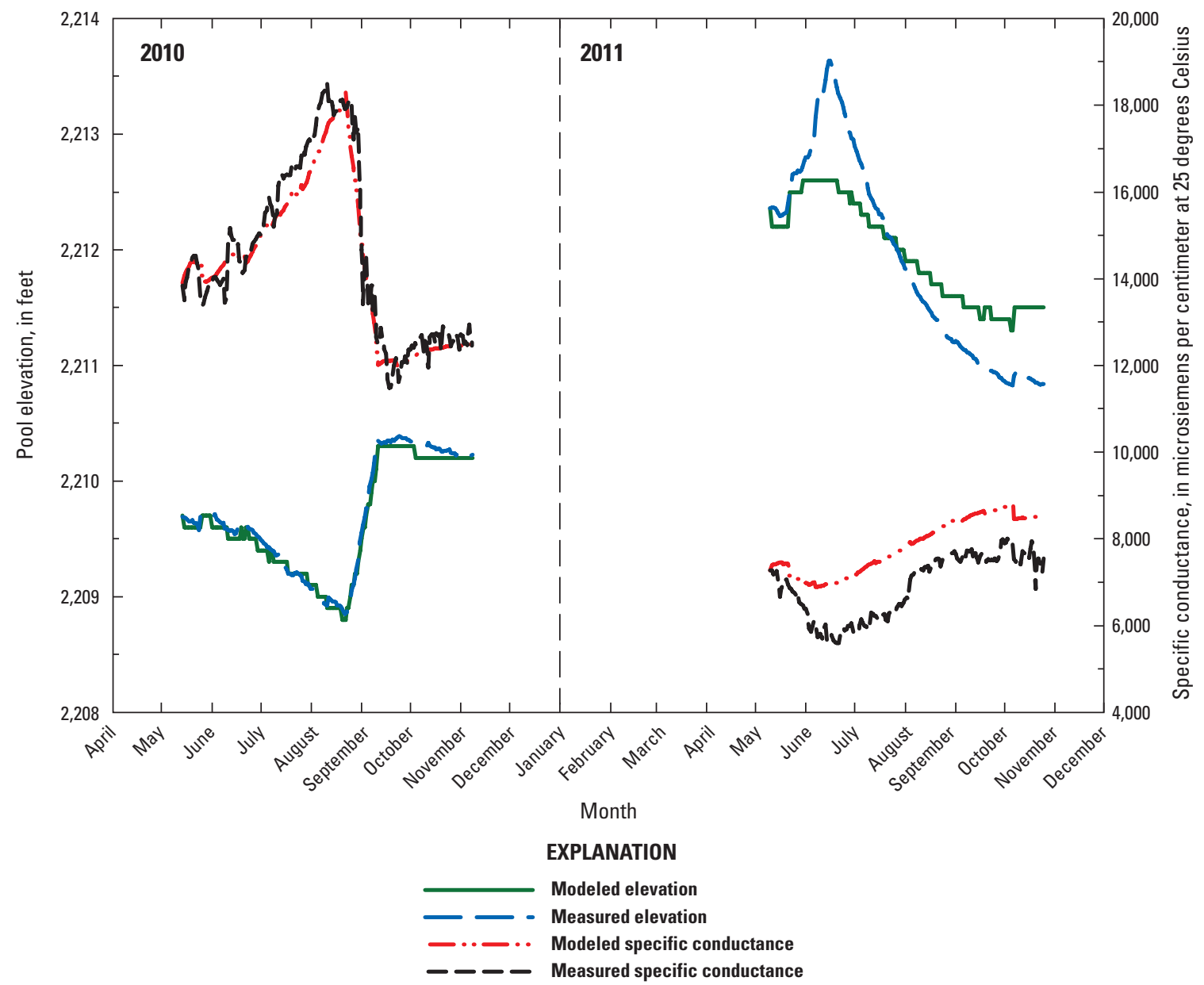

Figure 10. Modeled and measured pool elevation and specific conductance for Lake Bowdoin from May 14 to November 9, 2010, and May 10 to October 25, 2011. 
Table 1. Summary statistics comparing measured values to the 2010 and 2011 model simulations of Bowdoin, Long Lake, and Sand Lake National Wildlife Refuges.

[Annual mean, median, and maximum differences (absolute and percent) are presented for pool elevation and specific conductance. Absolute values are differences between modeled and measured pool elevation and specific conductance. Percentages were calculated using the absolute differences and measured and modeled values for specific conductance and pool elevation, respectively. $\mu \mathrm{S} / \mathrm{cm}$, microsiemens per centimeter at 25 degrees Celsius]

\begin{tabular}{|c|c|c|c|c|c|c|c|c|c|c|c|c|c|}
\hline \multirow{3}{*}{ Year } & \multirow{3}{*}{ Days } & \multicolumn{6}{|c|}{ Pool elevation } & \multicolumn{6}{|c|}{ Specific conductance } \\
\hline & & \multicolumn{3}{|c|}{ Absolute difference, feet } & \multicolumn{3}{|c|}{ Percent difference } & \multicolumn{3}{|c|}{ Absolute difference, $\mu \mathrm{S} / \mathrm{cm}$} & \multicolumn{3}{|c|}{ Percent difference } \\
\hline & & Mean & Median & Maximum & Mean & Median & Maximum & Mean & Median & Maximum & Mean & Median & Maximum \\
\hline 2010 & 180 & 0.06 & 0.05 & 0.26 & 1.8 & 1.62 & 7.55 & 415.9 & 351.37 & $1,874.17$ & 2.9 & 2.62 & 12.00 \\
\hline 2011 & 169 & 0.38 & 0.38 & 1.03 & 7.8 & 8.04 & 18.40 & 936.2 & 932.68 & $1,659.82$ & 12.1 & 11.24 & 20.23 \\
\hline 2010 & 211 & 0.27 & 0.29 & 0.99 & 4.2 & 4.41 & 15.77 & 116.0 & 91.81 & 449.97 & 8.2 & 6.91 & 29.93 \\
\hline 2011 & 169 & 0.33 & 0.34 & 0.60 & 4.7 & 4.83 & 8.64 & 188.6 & 149.37 & 439.45 & 16.8 & 12.29 & 39.48 \\
\hline \multicolumn{14}{|c|}{ Sand Lake National Wildlife Refuge } \\
\hline 2010 & 164 & 0.81 & 0.38 & 2.04 & 8.6 & 3.48 & 22.67 & 90.9 & 65.71 & 351.62 & 9.0 & 7.20 & 31.20 \\
\hline
\end{tabular}

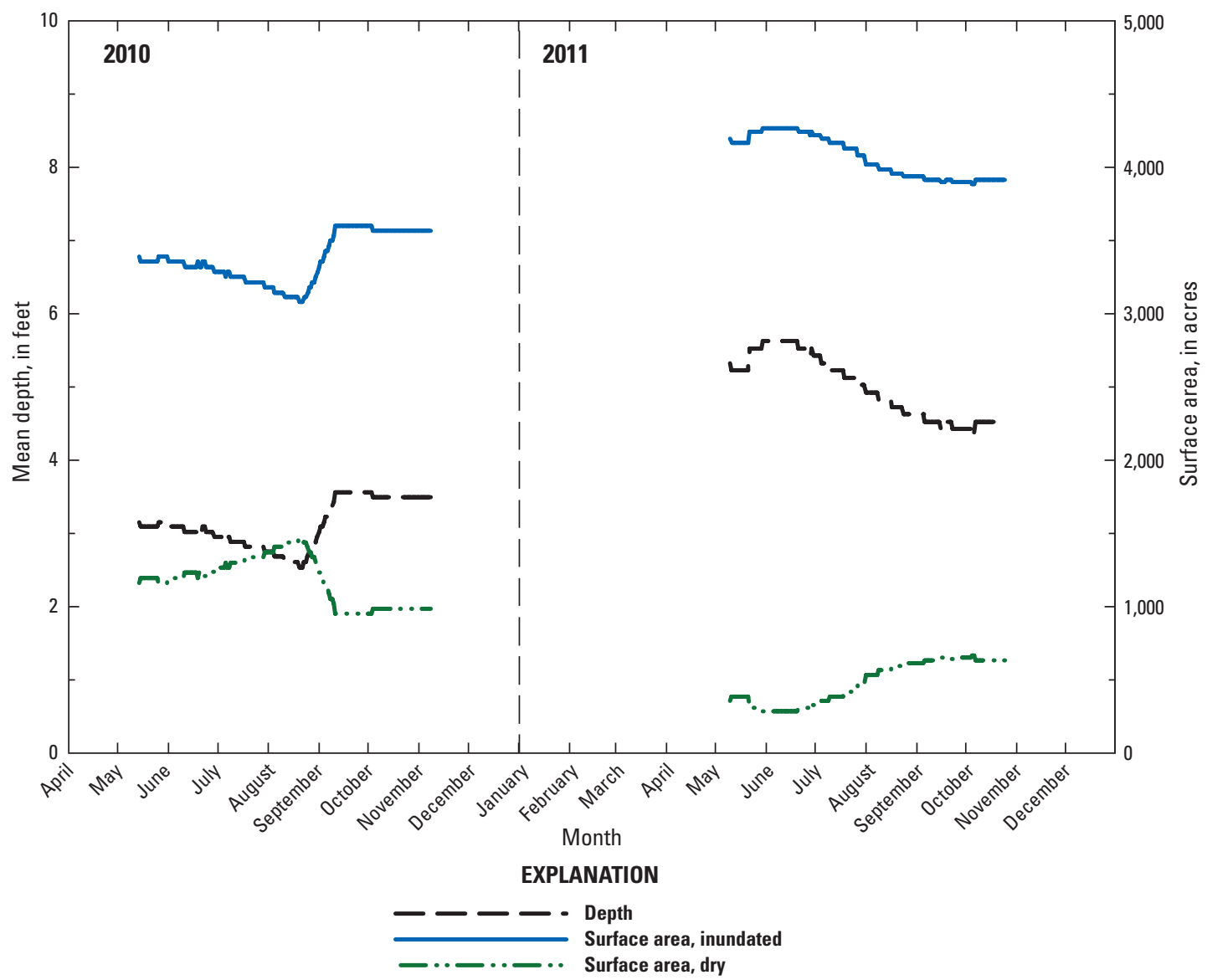

Figure 11. Modeled mean water depth and surface areas (inundated, dry) for Lake Bowdoin from May 14 to November 9, 2010, and May 10 to October 25, 2011. 


\section{Long Lake National Wildlife Refuge}

In general, the WSB model produced temporal patterns and trends of pool elevation and specific conductance that were similar to measured values (fig. 12, table 1). The mean daily absolute differences between modeled and measured pool elevation were $0.27 \mathrm{ft}$ for 2010 and $0.33 \mathrm{ft}$ for 2011 . These differences equated to approximately 4.2 percent and 4.7 percent of the mean modeled water depths for 2010 and 2011, respectively. Mean daily absolute differences between modeled and measured specific conductance levels were $116.0 \mu \mathrm{S} / \mathrm{cm}(8.2$ percent of observed mean) and $188.6 \mu \mathrm{S} / \mathrm{cm}$ (16.8 percent of observed mean) for 2010 and 2011, respectively. The model also provided estimates of mean water depth and surface areas (fig. 13) that are calculated using the surface area-capacity-depth curve; the precision of these estimates was not assessed.

Modeled mean pool elevations from the WSB model were, on average, within $0.33 \mathrm{ft}$ of measured values (fig. 12) despite the fact that water exchanges were not accounted for between Units 1 and 2; however, water levels were fairly consistent among Units 1 and 2 and flows were likely minimal. Overall, modeled elevation was consistently lower than measured elevation. Modeled specific conductance mimicked the overall observed seasonal trend during 2010 with greater divergence between estimated and measured values when specific conductance changed abruptly. During 2011, modeled specific conductance was more similar to measured values during the first part of the year, with greater divergence evident after the water levels began to drop steadily (fig. 12). The WSB model performance likely could be enhanced by increasing the accuracy of the stage-discharge curves, refining the relatively coarse surface area-capacity-depth curve, and developing a method to estimate water exchanges between Unit 1 and Unit 2. Further, expanding the WSB model to include Unit 2 , Unit 3, and Unit 2 marsh will require monitoring to quantify flows between all units and to estimate contributions from the local drainages.

\section{Sand Lake National Wildlife Refuge}

In general, the WSB model produced temporal patterns and trends of pool elevation and specific conductance that were similar to measured (mean for Mud and Sand Lake) values (fig. 14, table 1). The mean daily absolute differences between modeled and measured pool elevation were $0.81 \mathrm{ft}$

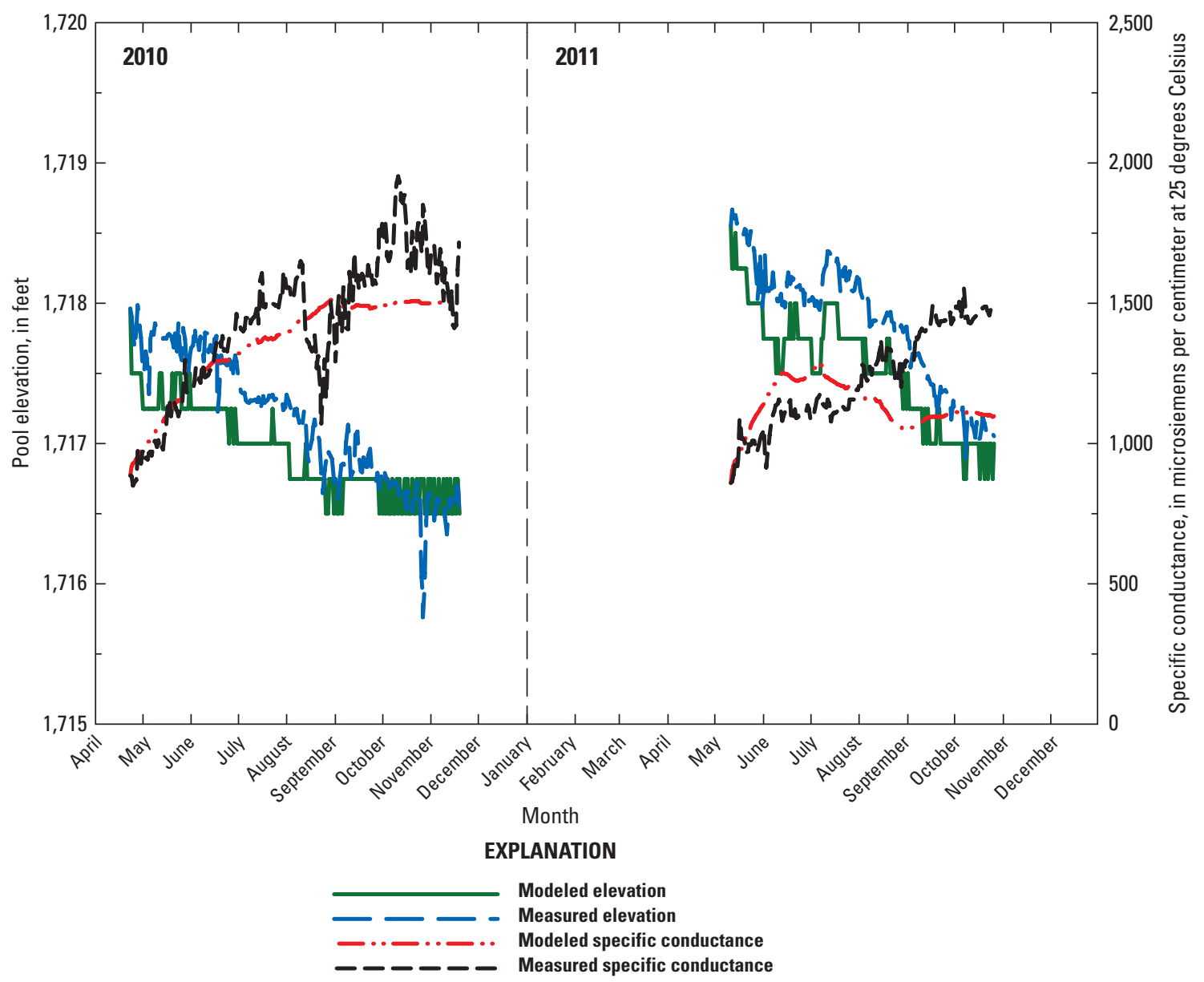

Figure 12. Modeled and measured pool elevation and specific conductance for Unit 1 of Long Lake National Wildlife Refuge from April 23 to November 19, 2010, and May 11 to October 26, 2011. 


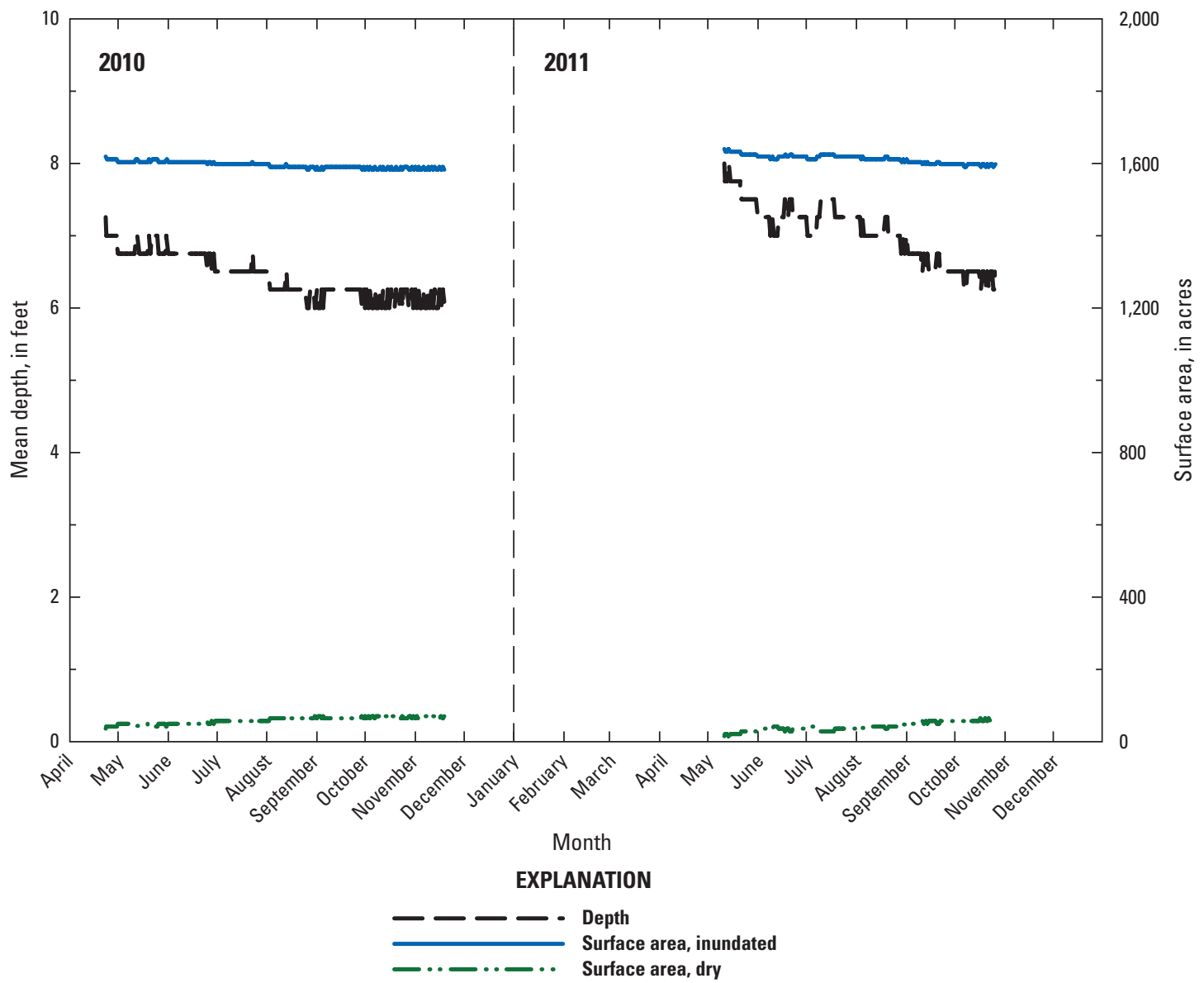

Figure 13. Modeled mean water depth and surface areas (inundated, dry) for Unit 1 of Long Lake National Wildlife Refuge from April 23 to November 19, 2010, and May 11 to October 26, 2011.

for 2010 and $0.43 \mathrm{ft}$. for 2011. These differences equated to approximately 8.6 percent and 3.4 percent of the mean modeled water depths for 2010 and 2011, respectively. Mean daily absolute differences between modeled and measured specific conductance levels were $90.9 \mu \mathrm{S} / \mathrm{cm}(9.0$ percent of observed mean) and $47.9 \mu \mathrm{S} / \mathrm{cm}(5.1$ percent of observed mean) for 2010 and 2011, respectively. The model also provided estimates of mean water depth and surface areas (fig. 15) that are calculated using the surface area-capacity-depth curve; the precision of these estimates was not assessed.

Overall, modeled specific conductance was very close to the measured values for both years (fig. 14). However, this is not surprising since Mud and Sand Lakes are freshwater flow-through systems with little seasonal variation in specific conductance. The WSB model also predicted mean pool elevation fairly well, although there was greater deviation between modeled and measured elevations during the fall of 2010 and spring and fall of 2011 (fig. 14). Despite this variation, the WSB model performance exceeded expectations given the data limitations. The WSB model performance likely would improve if sufficient data were available to develop more accurate stage-discharge curves.

\section{Discussion of Model Validation}

The WSB model was adapted to three NWRs, and modeled and measured trends were compared over the approximate ice-free parts of 2010 and 2011. Site-specific model input data and management information were used, and no model adjustments or calibrations were applied to improve simulation results. Modeled pool elevation and specific conductance values were, on average, within approximately 9 and 17 percent of reference values, respectively, based on absolute daily differences (figs. 10, 12, 14; table 1). Annual 


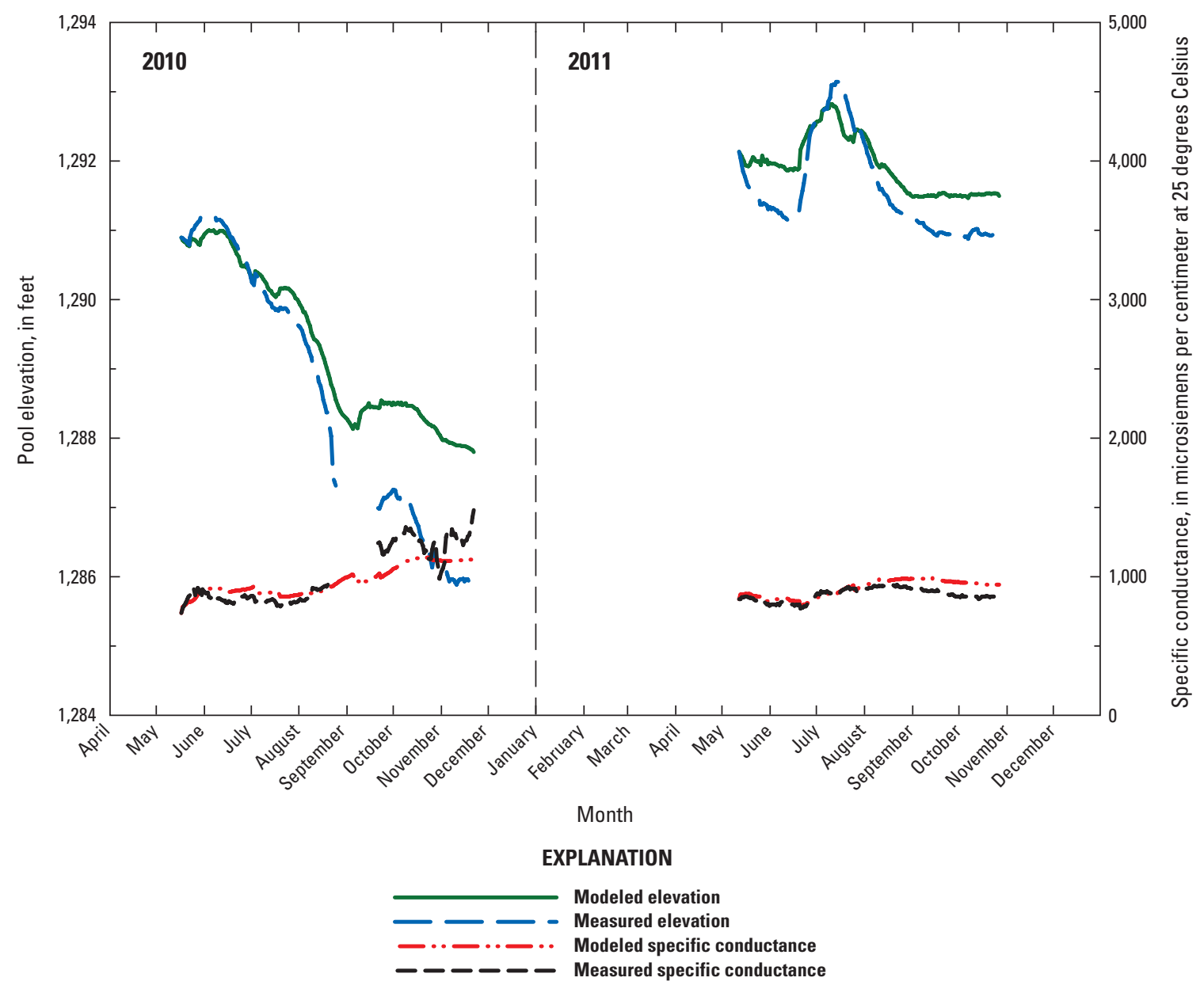

Figure 14. Modeled and measured pool elevation and specific conductance for Sand Lake National Wildlife Refuge from May 17 to November 22, 2010, and May 12 to October 27, 2011. Pool elevations and specific conductance values represent a mean for Mud and Sand Lakes. Gaps in the measured pool elevation and specific conductance data during 2010 are for periods where data were not available.

average differences between modeled and measured specific conductance ranged from $48-936 \mu \mathrm{S} / \mathrm{cm}$ (table 1). On the basis of relations between biotic communities and specific conductance (Gleason and others, 2009), these differences are small enough, in most cases, to not greatly affect ecological interpretation.

Modeled temporal trends were reasonably similar to measured trends when model input data were relatively complete; however, there were deviations among the modeled and measured trends when data were missing or when the model relied on relatively imprecise stage-discharge or surface-area-capacity curves. For example, the model produced temporal trends that were very similar to measured trends for Lake Bowdoin during 2010 when the input data were complete; modeled data showed divergence from measured trends during 2011 when estimates of water exchange with Beaver Creek were unavailable (fig. 10).

On the basis of these comparisons, the WSB model is capable of simulating the overall water and salt balance for managed wetland impoundments and can be used as a tool to evaluate habitat conditions associated with climate scenarios, management actions, or changes to water availability. Moreover, the successful application of the WSB model to a diversity of impoundments associated with varying data quality and availability demonstrated the model's flexibility and adaptive structure. As an example, the WSB model, which was unmodified for Lake Bowdoin, calculates surface outflow on the basis of water-control structure elevation. For application to LLNWR and SLNWR, the model was modified to calculate outflow using a stage-discharge curve.

The performance of the WSB model validates the decision to simplify the original BNWR model (Hamilton and others, 1989) to account for only the primary sources of water and salts. If some of the secondary sources (for example, groundwater) had a large effect, at least in the short term, the WSB model would not have predicted trends as well as it did. However, small amounts of salts contributed by secondary sources can accumulate over time and eventually have a significant impact. Further, direct surface runoff would be considered a primary water source if model simulations 


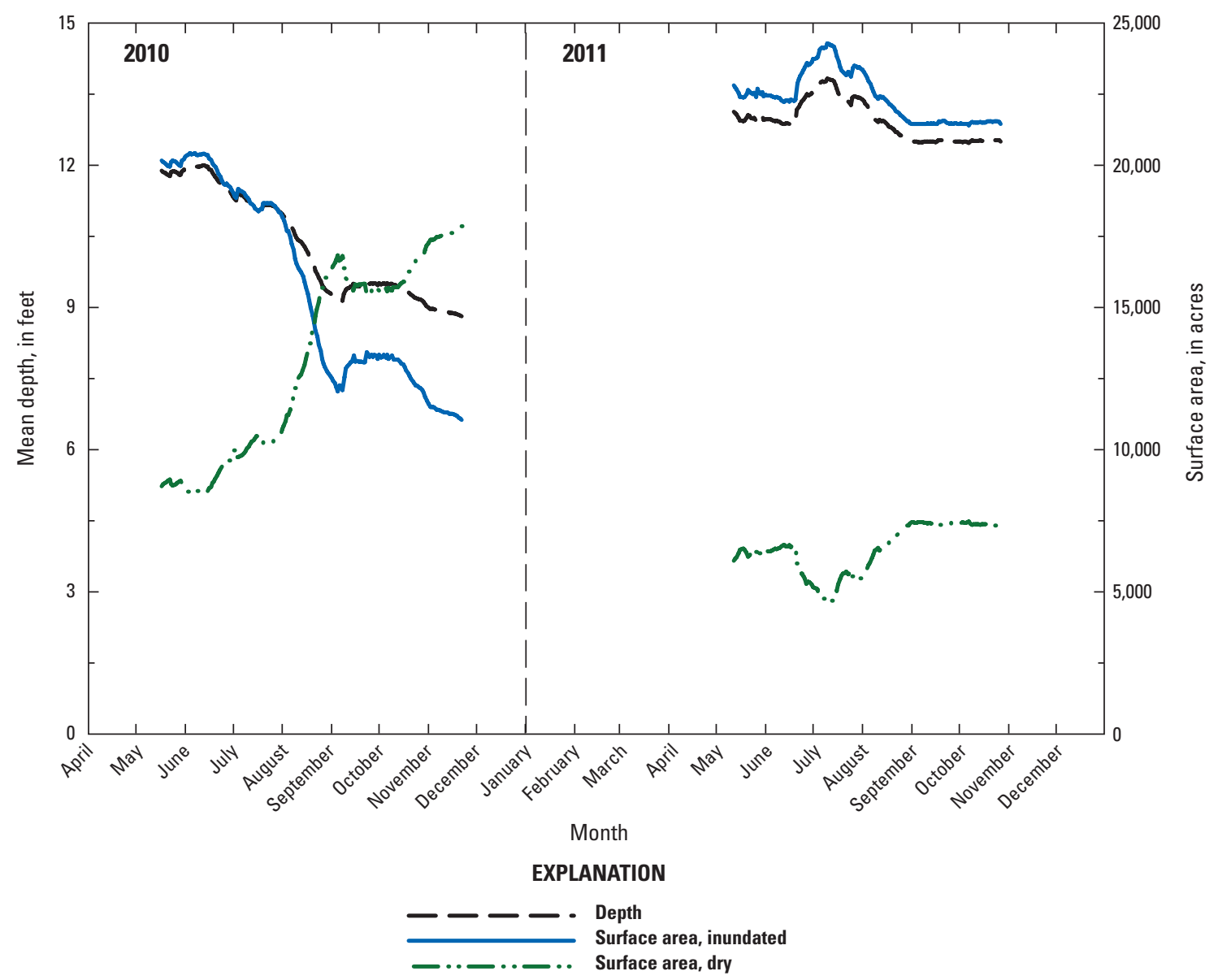

Figure 15. Modeled mean water depth and surface areas (inundated, dry) for Sand Lake National Wildlife Refuge from May 17 to November 22, 2010, and May 12 to October 27, 2011. Values were modeled using the combined surface area-capacity-depth curve for Mud and Sand Lakes.

had been performed across periods that included snowmelt; however, the WSB model is structured so that additional data, such as snowmelt runoff, can be easily incorporated. For the WSB model, direct surface runoff attributed to overland flow was not included because most impoundments on NWRs in the region are surrounded by relatively low-relief grasslands, dikes, and elevated roadbeds; therefore, the potential for large amounts of direct surface runoff from precipitation generally is low.

The simple WSB model simulated the overall water and salt balance of managed impoundments, on average, within 17 percent of measured values (table 1). Model performance for a given impoundment, however, could be improved with more accurate calculations of variables such as surface area, volume, depth, and discharge. As an example, more precise surface area-capacity-depth curves, and stage-discharge curves developed for a range of water-control structure elevations, could greatly improve, in many instances, model performance. Similarly, the ability to accurately predict inputs from local drainages, which often contribute significant amounts of water to refuge impoundments, would be extremely beneficial. Further, the WSB model provides only rough estimates of surface areas (inundated, dry) and a mean depth for the impoundment. Incorporation of the WSB model into a spatial geographic information system (GIS) framework, in conjunction with high-resolution bathymetry data, would provide a more detailed description of habitat characteristics by depicting variables such as water depth or surface area of mud flats in a spatially-explicit manner.

\section{Results of Model Application to Bowdoin National Wildlife Refuge}

\section{Simulation Results}

Results from the three 50-year and three single-year simulations are presented graphically for BNWR. The black lines represent simulations based on the WRF climate projections and average canal inputs from previous years (climate 
simulation) for figures $16-20$. The remaining lines represent simulations based on the climate projections and modifications to the average canal deliveries (management simulations); blue and green lines represent 80 and 120 percent of the average canal deliveries, respectively.

The 50-year climate simulation of Lake Bowdoin (black line in fig. 16) showed an initial increase in water depth, which approached the maximum depth within approximately 10 years. Water depth fluctuated but remained relatively stable thereafter (fig. 16A). The simulation predicted an overall reduction in specific conductance levels, primarily owing to salt losses through surface flows (fig. 16B). Mean annual specific conductance decreased from 7,138 to $2,434 \mu \mathrm{S} / \mathrm{cm}$ over the simulation period, a decrease of approximately 66 percent. Similar to depth, the simulation showed that the inundated and dry surface areas consistently approached the maximum and minimum levels, respectively (fig. 16C). The mass of salts declined greatly over the simulation period, with a decrease in the mean annual mass of approximately 73,000 tons over the simulation period (fig. 16D).

The 50-year management simulations of Lake Bowdoin (fig. 16) resulted in water depths and surface areas that were comparable to the climate scenario (fig. 16A, 16C). Overall, depths for the 80-percent scenario were slightly lower compared to the average scenario while depths from the 120-percent scenario were slightly greater than the average scenario. Inundated and dry surface areas corresponded to the changes in depth. Trends in specific conductance and mass of salts also were similar among the climate and management scenarios, but the magnitude of change varied over the simulation period (fig. 16B, 16D). The 80-percent scenario resulted in the highest specific conductance levels while the 120-percent scenario resulted in the lowest. The variation in specific conductance among the scenarios was primarily because of the greater loss of salts through surface outflow associated with the higher inflow scenarios (100 and 120 percent). Although the increased-delivery scenario resulted in more imported salts than the reduced-delivery scenario, greater water losses resulted in a nearly 78,000 ton difference in the mass of salts between the two management simulations (fig. 16D).

Overall, relations among the three scenarios were similar between the single-year and 50-year simulations (figs. 16, 17). The exception was mass of salts, which showed opposing patterns among the management scenarios (figs. $16 D, 17 D$ ). The 80 -percent scenario resulted in the greatest mass of salts for the 50-year simulation, while the 120 -percent scenario resulted in the greatest mass for the single-year simulation. These simulations differed with respect to salt mass because pool elevation did not exceed the water-control structure elevation during the single-year simulation; thus, there were no surface outflows that resulted in the loss of salts. Additionally, the overall magnitude of changes from the beginning to the end of the simulations, especially for specific conductance and mass of salt, were much smaller for the single-season simulations because of the shorter timeframe. However, if these small changes were extrapolated over time, they could become significant.

The single-year simulations displayed patterns in all variables that were associated primarily with seasonal precipitation, ET, and canal deliveries (fig. 17). Water depth remained constant until approximately June when water levels declined because ET exceeded water inputs. Water levels increased during late summer and fall because of increased canal inputs, primarily in September (fig 17A). Patterns in surface areas corresponded to changes in depth (fig. 17C). Similarly, specific conductance displayed a seasonal trend associated with concentration and dilution effects as water levels declined and rose $(17 B)$. Although the 120-percent delivery scenario resulted in the greatest mass of salt, it displayed the lowest specific conductance because of dilution associated with higher water inputs.

The 50-year simulations (climate and management) of Lake Bowdoin that included 2020 and 2040 Beaver Creek flood events showed similar relations among the three scenarios as those that did not include floods (figs. 16, 18). The simulated floods, however, did result in greater losses of salts to outflow and lower specific conductance levels when compared to the nonflood simulations (figs. 16B, 16D, 18B, 18D). Further, the simulated floods resulted in noticeable decreases in specific conductance levels because of the removal of salts and dilution effects (figs. 18B, 18D). Differences in water depths between the flood and nonflood simulations were minimal because pool elevations remained near the maximum level, and water was lost to surface flow when this level was exceeded.

\section{Discussion of Model Application}

Results from the Lake Bowdoin simulations (figs. 16-18) suggest that the climate and management scenarios would result in near-maximum water depths and reduced specific conductance levels compared to recent observed conditions (figs. 4, 8). These model simulations demonstrate how a future climate characterized by above-average precipitation (fig. 9), compared to past and current observations, could have major impacts to an impoundment by increasing and stabilizing water levels and reducing salinity levels. The simulations also demonstrate the importance of management in terms of affecting habitat characteristics such as salinity and depth (fig. 16). Managers can manipulate depth and salinity levels of a closed-basin system in numerous ways. For example, the mass of salts could be decreased by limiting salt inputs associated with managed water inputs, but if water volumes also are decreased, specific conductance values may increase. Conversely, increasing water inputs (or lowering the water-control structure elevation) could result in a significant export of salts through surface flow, and the remaining salts could be diluted by the greater volume of water. In reality, when making management decisions, USFWS personnel must simultaneously consider all components that affect an impoundment's water 

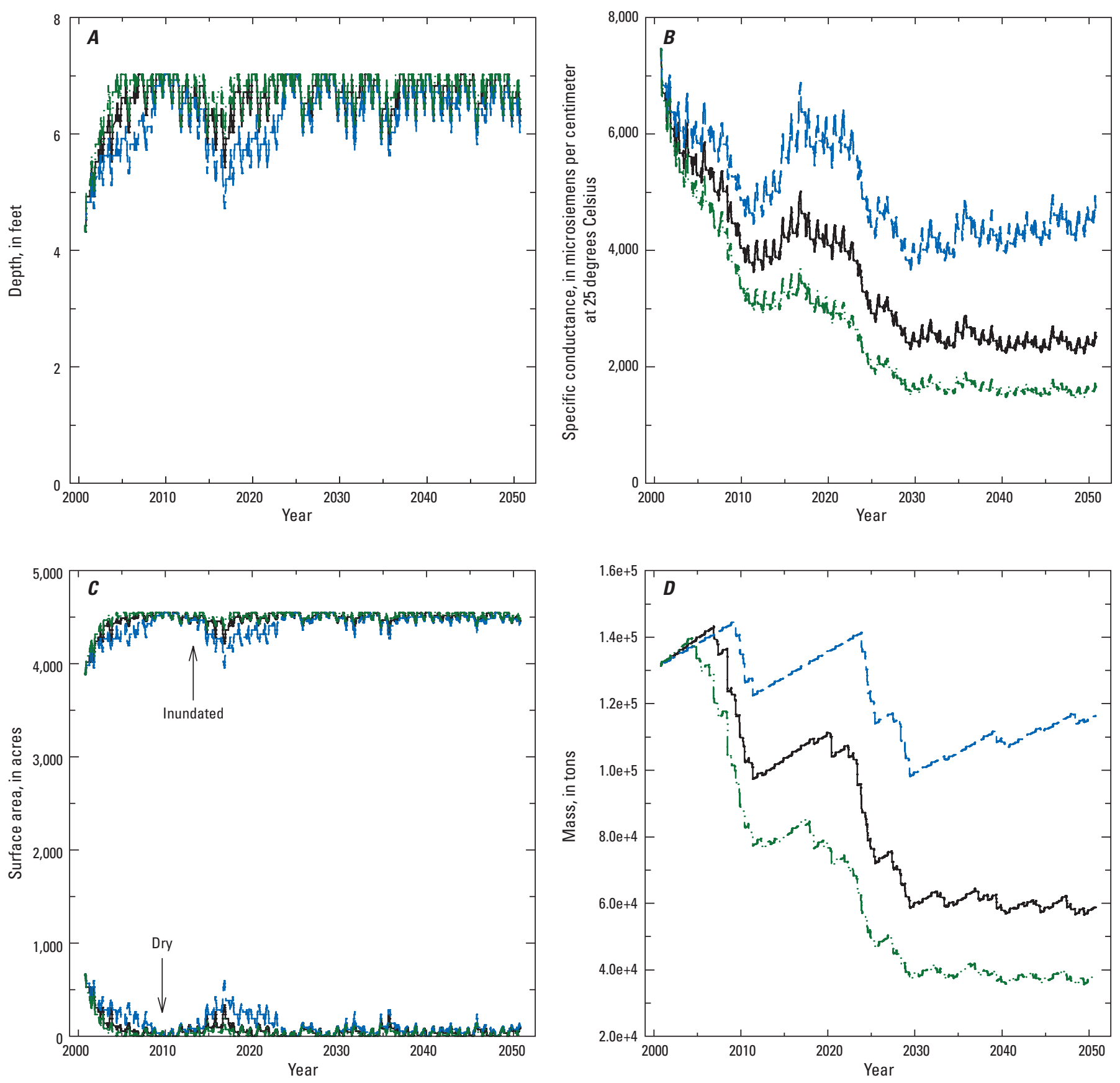

\section{EXPLANATION}

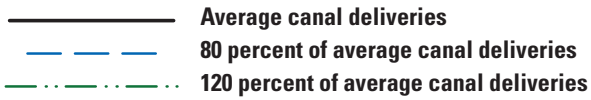

Figure 16. Results from the 50-year model simulations of Lake Bowdoin. $A$, Mean water depth; $B$, Specific conductance; $C$, Inundated and dry surface areas; and $D$, Mass of salts. 

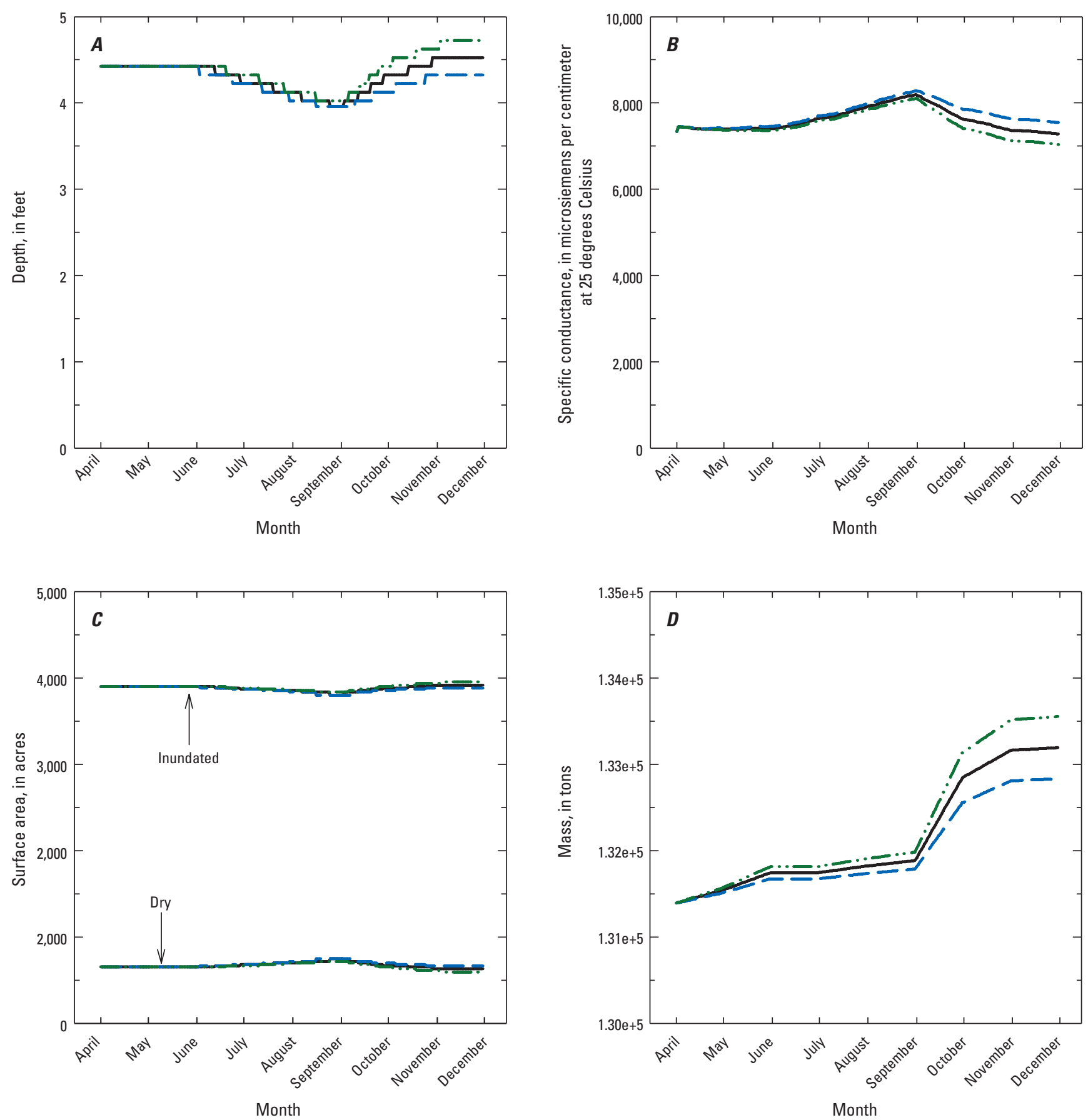

EXPLANATION

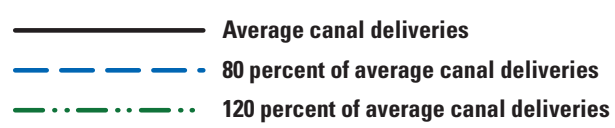

Figure 17. Results from the single-year model simulations of Lake Bowdoin. $A$, Mean water depth; $B$, Specific conductance; $C$, Inundated and dry surface areas; and $D$, Mass of salts. 

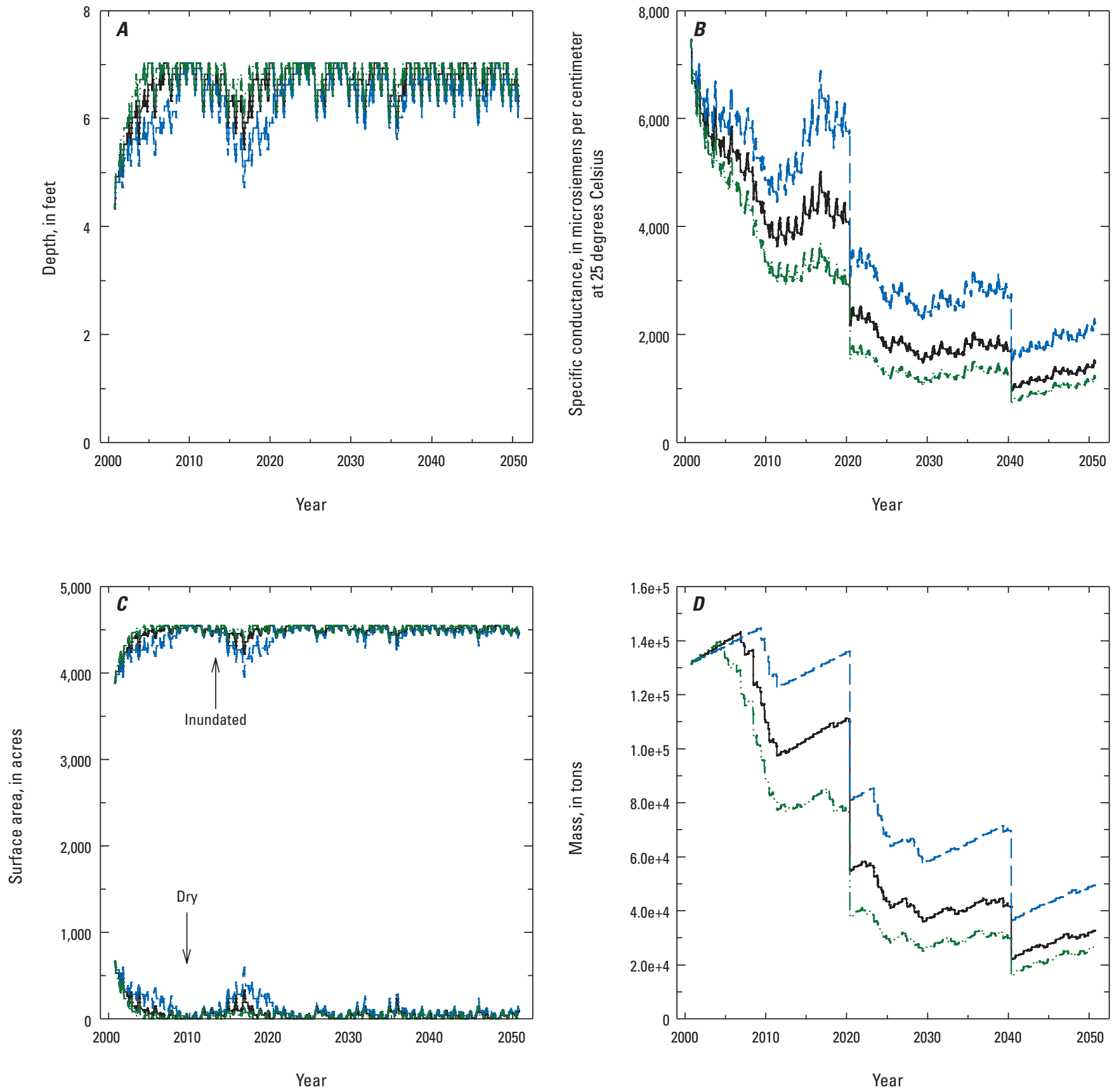

EXPLANATION

Average canal deliveries

- - - 80 percent of average canal deliveries

$\ldots-\cdots-\cdots 120$ percent of average canal deliveries

Figure 18. Results from the 50-year model simulations of Lake Bowdoin that included Beaver Creek floods. $A$, Mean water depth; $B$, Specific conductance; $C$, Inundated and dry surface areas; and $D$, Mass of salts. 


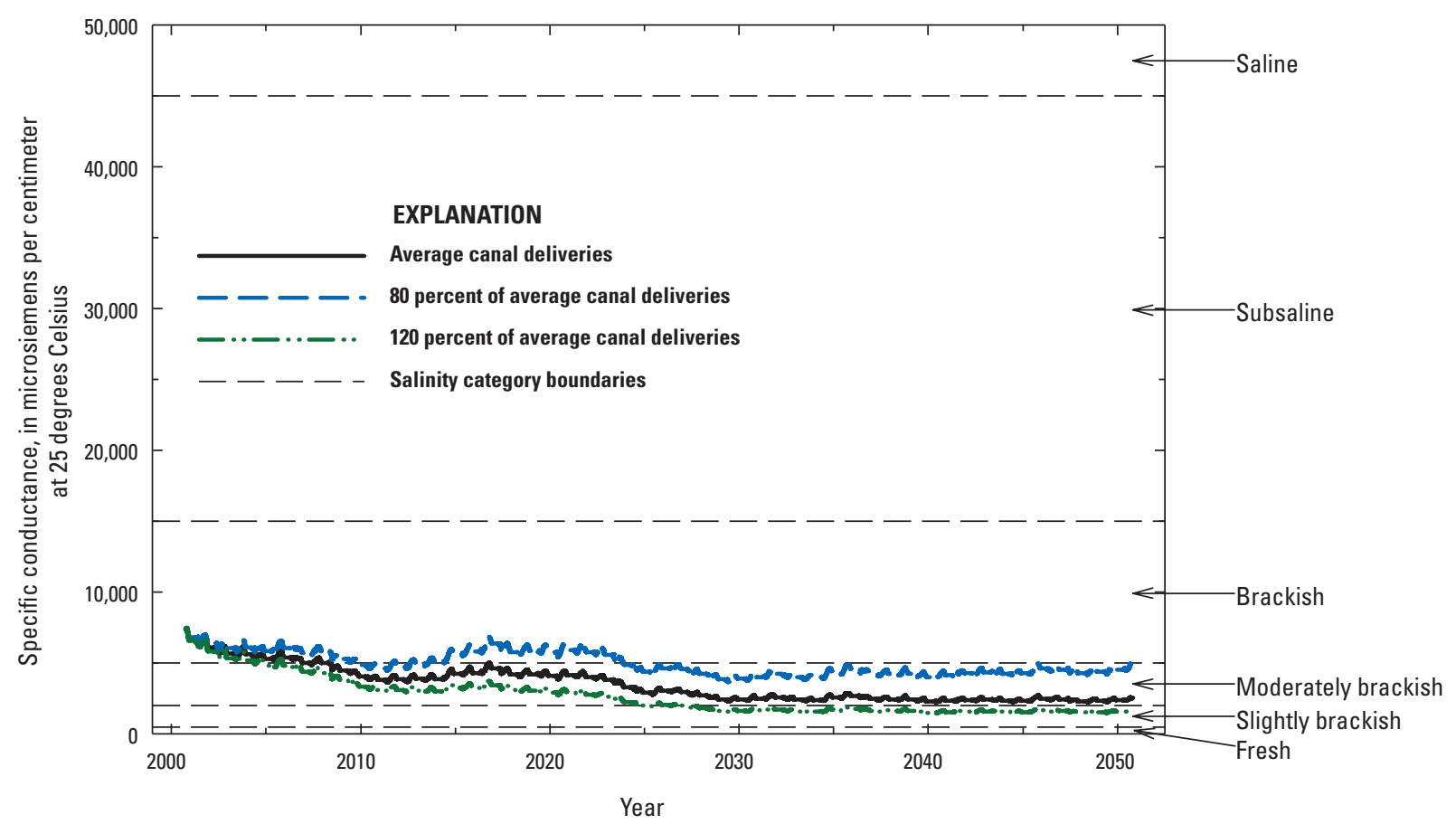

Figure 19. Specific conductance from the 50-year model simulations of Lake Bowdoin overlain with salinity category boundaries.

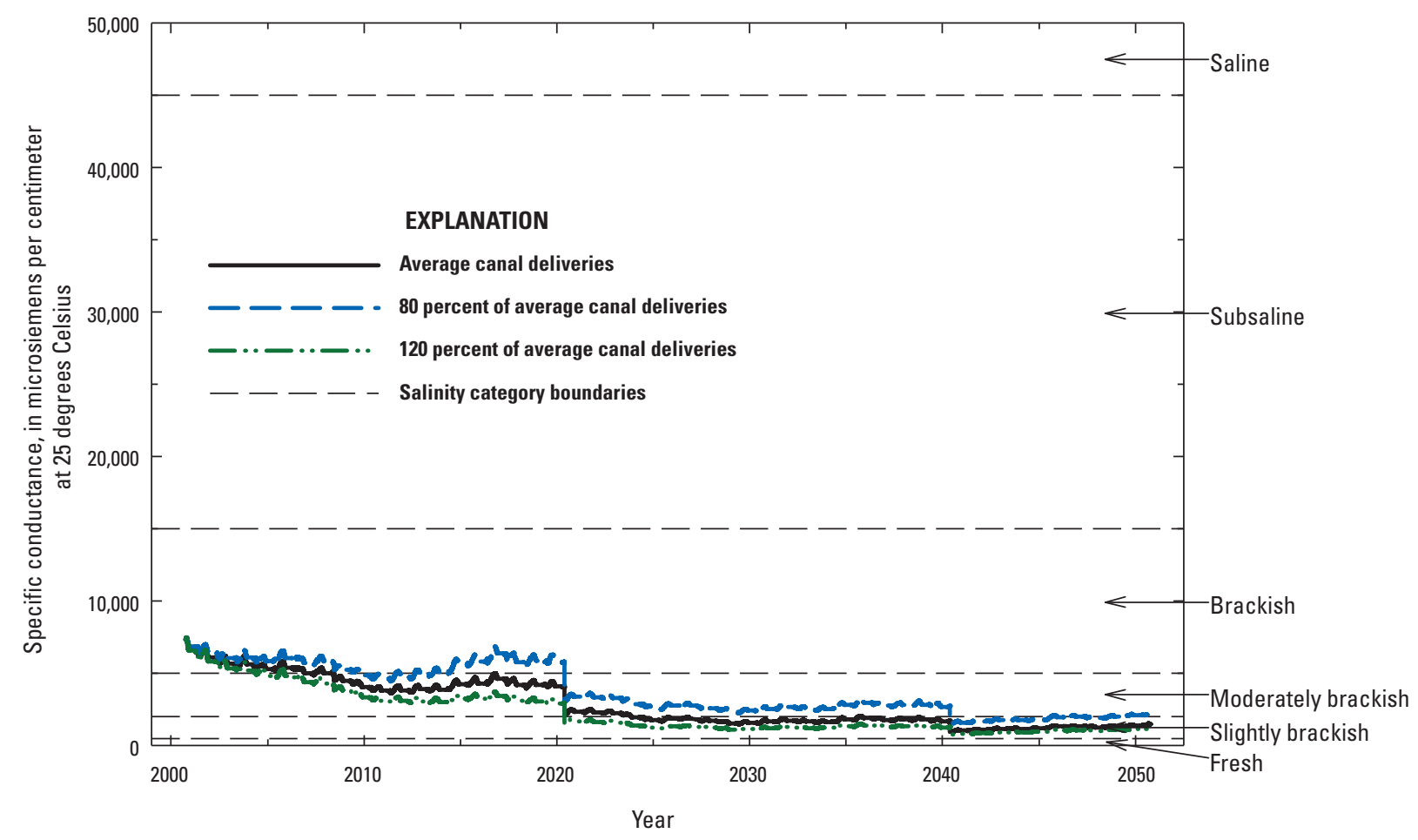

Figure 20. Specific conductance from the 50-year model simulations of Lake Bowdoin that included Beaver Creek floods overlain with salinity category boundaries. 
balance, as well as factors such as biological goals and the availability of water for management.

Simulation results also demonstrate the importance of periodic Beaver Creek floods to regulating salinity levels of Lake. The flood simulations included two floods events, both of which noticeably reduced specific conductance and mass of salts (fig. 18). The abrupt changes in specific conductance associated with the simulated floods corresponded well to the observed changes associated with the two most recent Beaver Creek floods (fig. 8). These simulations, along with the past observations, demonstrate how natural events such as floods can play an important role in maintaining salinity levels over time by periodically flushing and diluting salts.

The example application of the WSB model to Lake Bowdoin demonstrated its utility for depicting various habitat characteristics in response to changes in factors that affect an impoundment's water balance. However, model results must be related to biological goals and objectives to support the USFWS's conservation-oriented management. Lake Bowdoin simulation results are discussed in the following text in terms of their implications to biotic communities of the lake.

Gleason and others (2009) presented the mean annual specific conductance levels for Lake Bowdoin from 19752007 along with wetland salinity categories (Stewart and Kantrud, 1972) that ranged from fresh to saline. These data showed that Lake Bowdoin typically falls within the brackish category but oscillates from moderately brackish to subsaline in response to concentration (for example, pool drawdown because of drought) and dilution (for example, Beaver Creek floods) episodes.

Gleason and others (2009) also performed a literature review and used the resulting data to depict the optimal salinity levels for common aquatic plant and invertebrate taxa. Results from this review indicate that most taxa are found in waters classified as moderately brackish (less than 5,000 $\mu \mathrm{S}$ / $\mathrm{cm}$ ) or fresher, and that taxon diversity is reduced when salinity levels approach or exceed subsaline (greater than 15,000 $\mu \mathrm{S} / \mathrm{cm}$ ). Thus, an obvious management objective would be to maintain salinity levels in the fresh to moderately brackish range. In the case of Lake Bowdoin, moderately brackish waters would be an appropriate target because the lake is naturally brackish, and this would be within the normal range of variation for this geographic location. When the Stewart and Kantrud (1972) salinity categories are superimposed on model results for specific conductance (figs. 19-20) inferences pertaining to the effects of climate, management, and flood scenarios on the biotic communities of Lake Bowdoin can be made.

On the basis of these straightforward comparisons, it is evident all simulations resulted in relatively stable salinity levels ranging from slightly brackish to brackish (figs. 19-20); thus, the conditions that these simulations were founded on would result in habitat characteristics favorable for most aquatic plants and invertebrates currently inhabiting the lake (Gleason and others, 2009). It is important to note, however, that model scenarios were based on various assumptions such as consistent canal deliveries and management among years and relied on modeled climate data based on a single emission scenario. Further, no guidance was provided by wetland managers pertaining to any proposed management plans. Thus, results are not meant to guide management; rather, the simulations are a demonstration of the WSB model's utility.

In summary, various model simulations of Lake Bowdoin were performed with the purpose of demonstrating how the WSB model can be used as a management tool. In doing so, potential habitat characteristics were depicted based on a future climate scenario and the results demonstrated how two opposing management actions and natural flood events may affect these characteristics. Simulations such as these will allow wetland managers to assess potential effects to various habitat metrics from changes to climate and water availability, or alternative management objectives or strategies. Although simulations were limited by various assumptions and constrained by several simulation parameters (for example, A2 climate scenario), results demonstrated potential effects of a wetter and warmer climate, management (water and salt deliveries), and natural floods to the water and salt balance of Lake Bowdoin.

\section{Summary and Conclusions}

The water and salt balance (WSB) model was described and validated using three geographically distinct National Wildlife Refuges (NWRs) with unique data limitations and differing relations to water resources associated with rivers. Overall, the WSB model simulated temporal trends in specific conductance and pool elevation (depth) that were comparable to measured trends over the 2-year simulation period. However, model accuracy and the magnitude of differences between modeled and observed values varied seasonally and among refuges. Model performance would be expected to improve by addressing various data limitations relating to factors such as water inputs and losses, impoundment bathymetry, and water discharge rates. Further, application of site-specific calibrations or adjustments likely would improve model performance.

Simulations of Lake Bowdoin demonstrated how the WSB model can be used as a management tool for assessing various habitat characteristics in light of long-term changes to climate and water availability and alternative management actions. This exercise also highlighted the importance of longterm monitoring and data collection to facilitate development of model simulations and to support biological interpretations of results.

The water balance of managed impoundments associated with rivers can be affected in various ways by climate, water availability, and management. The WSB model allows for predictions of habitat conditions based on water inputs, losses, and management. This type of model can be very effective when applied to closed-basin systems with an 
indirect connection to a river (for example, Lake Bowdoin) because riverine inputs are regulated by wetland managers, and estimates of actual streamflow are not required to evaluate management scenarios. Conversely, "in-stream" refuges with direct connections to rivers (for example, Sand Lake NWR) have more limited management capabilities, and any modeling efforts would be highly dependent on streamflow estimates for inputs.

One approach to conduct scenario-based modeling for these flow-through type of systems would be to use historic streamflow data associated with specific climatic periods (for example, extreme wet/dry periods) that emulate anticipated climate conditions to evaluate proposed future management actions across a range of observed conditions. For example, figure 7 shows streamflow for the James River and Palmer Modified Drought Index (PMDI) values from 1981-2012. This figure demonstrates the relation between overall moisture patterns (PMDI) and river flows and could be used to identify a range of conditions for modeling exercises. Another approach, which would be especially desirable when evaluating potential climate change, would be to model streamflow stratified by specific conditions such as increased temperatures, earlier snowmelt, and decreased precipitation. However, streamflow is dependent not only on weather patterns but on runoff and water management upstream in the watershed. Processes such as reservoir management and watershed runoff are complex and difficult to predict and model, which limits the ability of the model to comprehensively evaluate the effects of predicted climate change to river impoundments. To address this limitation, future monitoring and research efforts should also include development and calibration of watershed models (for example, Precipitation-Runoff Modeling System) to estimate streamflow.

Personnel of NWRs throughout the northern Great Plains face management challenges associated with climate change, altered water supplies, and increasing salinity levels that have, or could potentially lead to, altered and diminished aquatic habitats that are critical to fulfilling a primary NWR System mission. To adequately address these challenges, wetland managers must be able to forecast the effects of various alterations to a system's water balance in order to make informed decisions. The WSB model presented in this report can be used as a tool for evaluating alternative management goals and objectives by simulating important habitat characteristics of impoundments in light of changes to climate, management actions, and water availability.

\section{References Cited}

Anderson, M.T., and Norton, P.A., 2007, Trends in streamflow in the Missouri River Basin from 1957 to 2006: Eos, Transactions, American Geophysical Union, Abstract GC13A-0952: accessed April 1, 2012, at http://www.agu. org/meetings/fm07/? content=program.
Anderson, M.T., Stamm, J.F., and Norton, P.A., 2008, Changes in monthly streamflow conditions in the Missouri River Basin from 1957 to 2007: Eos, Transactions, American Geophysical Union, Abstract H11I-02: accessed April 1, 2012, at http://www.agu.org/meetings/fm08/index.php/Program/ HomePage.

Anderson, M.T., and Woosley, L.H., Jr., 2005, Water availability for the Western United States-Key scientific challenges: U.S. Geological Survey Circular 1261, 85 p.

Badh, A., and Akyuz, A., 2010, Studying climate change and precipitation trends for North Dakota, United States: International Journal of Climate Change-Impacts and Responses, v. 2, p. 97-108.

Baskin, C.C., and Baskin, J.M., 1998, Seeds-Ecology, biogeography, and evolution of dormancy and germination: San Diego, Calif., Academic Press, 666 p.

Brekke, L.D., Kiang, J.E., Olsen, J.R., Pulwarty, R.S., Raff, D.A., Turnipseed, D.P., Webb, R.S., and White, K.D., 2009, Climate change and water resources management-A federal perspective: U.S. Geological Survey Circular 1331, $65 \mathrm{p}$.

Bridgham, S.D., Johnston, C.A., Pastor, J., and Updegraff, K., 1995, Potential feedbacks of northern wetlands on climate change: BioScience, v. 45, p. 262-274.

Colwell, M.A., and Taft, O.W., 2000, Waterbird communities in managed wetlands of varying water depth: Waterbirds, v. 23 , p. $45-55$.

Field, C.B., Mortsch, L.D., Brklacich, M., Forbes, D.L., Kovacs, P., Patz, J.A., Running, S.W., and Scott, M.J., 2007, North America, in Parry, M.L., Canziani, O.F., Palutikof, J.P., van der Linden, P.J., and Hanson, C.E., eds., Climate change 2007: Impacts, adaptation and vulnerability-Contribution of working group II to the Fourth Assessment Report of the Intergovernmental Panel on Climate Change: Cambridge, United Kingdom, Cambridge University Press, p. 618-652.

Fredrickson, L.H., 1991, Strategies for water level manipulations in moist-soil systems: Washington, D.C., U.S. Fish and Wildlife Service, Waterfowl Management Handbook, Fish and Wildlife Leaflet 13.4.6, 8 p.

Gleason, R.A., Euliss, N.H., Jr., and Homes, C.W., 2003, Sedimentation rates in the marshes of Sand Lake National Wildlife Refuge: U.S. Geological Survey Quick Response Project QR-F6-00-07, 27 p.

Gleason, R.A., Tangen, B.A., Laubhan, M.K., Finocchiaro, R.G., and Stamm, J.F., 2009, Literature review and database of relations between salinity and aquatic biota-Applications to Bowdoin National Wildlife Refuge, Montana: U.S. Geological Survey Scientific Investigations Report 2009-5098, 76 p. 
Hamilton, D.B., Roelle, J.E., and Schafer, W.M., 1989, A simulation model of water and salt balance at Bowdoin National Wildlife Refuge: Fort Collins, Colo., U.S. Fish and Wildlife Service, National Ecology Research Center, NERC-89/08, 60 p.

Hammer, U.T., and Heseltine, J.M., 1988, Aquatic macrophytes in saline lakes of the Canadian prairies: Hydrobiologia, v. 158 , p. 101-116.

Jensen, M.E., and Haise, H.R., 1963, Estimating evapotranspiration from solar radiation: Journal of the Irrigation and Drainage Division, Proceedings of American Society of Civil Engineers, v. 89, p. 15-41.

Johnson, W.C., Werner, B., Guntenspergen, G.R., Voldseth, R.A., Millett, B., Naugle, D.E., Tulbure, M., Carroll, R.W.H., Tracy, J., and Olawsky, C., 2010, Prairie wetland complexes as landscape functional units in a changing climate: BioScience, v. 60, p. 128-140.

Karl, T.R., and Koscielny, A.J., 1982, Drought in the United States-1895-1981: Journal of Climatology, v. 2, p. 313329.

Karl, T.R., Melillo, J.M., and Peterson, T.C., eds., 2009, Global climate change impacts in the United States: New York, N.Y., Cambridge University Press, 192 p.

Kendy, E., 1999, Simulation of water and salt budgets and effects of proposed management strategies for Bowdoin National Wildlife Refuge, northeastern Montana: U.S. Geological Survey Water-Resources Investigations Report 98-4260, 86 p.

Laubhan, M.K., Gleason, R.A., Knutsen, G.A., Laubhan, R.A., and Euliss, N.H., Jr., 2006, A preliminary biological assessment of Long Lake National Wildlife Refuge Complex, North Dakota: U.S. Department of Interior, Fish and Wildlife Service, Biological Technical Publication, BTP R6006-2006, 66 p.

Leavesley, G.H., Lichty, R.W., Troutman, B.M., and Saindon, L.G., 1983, Precipitation-runoff modeling system-User's manual: U.S. Geological Survey Water-Resources Investigations Report 83-4238, 207 p.

Ma, Z., Cai, Y., Li, B., and Chen, J., 2010, Managing wetland habitats for waterbirds: An international perspective: Wetlands, v. 30, p. 15-27.

Markstrom, S.L., Hay, L.E., Ward-Garrison, C.D., Risley, J.C., Battaglin, W.A., Bjerklie, D.M., Chase, K.J., Christiansen, D.E., Dudley, R.W., Hunt, R.J., Koczot, K.M., Mastin, M.C., Regan, R.S., Viger, R.J., Vining, K.C., and Walker, J.F., 2012, Integrated watershed-scale response to climate change for selected basins across the United States: U.S. Geological Survey Scientific Investigations Report 20115077, 143 p.
McGuinness, J.L., and Bordne, E.F., 1972, A comparison of lysimeter-derived potential evapotranspiration with computed values: U.S. Department of Agriculture, Agricultural Research Service, Technical Bulletin No. 1452, 71 p.

MESOWEST, 2012a, Web site for weather station MATM: accessed April 1, 2012, at http://mesowest.utah.edu/cgi-bin/ droman/meso_base.cgi?stn=MATM.

MESOWEST, 2012b, Web site for weather station TS633: accessed April 1, 2012, at http://mesowest.utah.edu/cgi-bin/ droman/meso_base.cgi?stn=TS633.

Millett, B., Johnson, W.C., and Guntenspergen, G., 2009, Climate trends of the North American prairie pothole region 1906-2000: Climatic Change, v. 93, p. 243-267.

Nakićenović, N., and Swart, R., eds., 2000, Special report on emission scenarios: A special report of working group III of the Intergovernmental Panel on Climate Change: Cambridge University Press, United Kingdom, 612 p.

National Oceanic and Atmospheric Administration, 2012, National climatic data center: accessed April 1, 2012, at http://www.ncdc.noaa.gov/oa/ncdc.html.

Neitsch, S.L., Arnold, J.G., Kiniry, J.R., and Williams, J.R., 2011, Soil and water assessment tool theoretical documentation-Version 2009: College Station, Tex., Texas A\&M University System, Texas Water Resources Institute Technical Report No. 406, 618 p.

Niemuth, N.D., Estey, M.E., Reynolds, R.E., Loesch, C.R., and Meeks, W.A., 2006, Use of wetlands by spring-migrant shorebirds in agricultural landscapes of North Dakota's drift prairie: Wetlands, v. 26, p. 30-39.

Nimick, D.A., McCarthy, P.M., and Fields, V., 2011, A digital model for planning water management at Benton Lake National Wildlife Refuge, west-central Montana: U.S. Geological Survey Scientific Investigations Report 2011-5133, $28 \mathrm{p}$.

North Dakota Agricultural Weather Network, 2012, North Dakota Agricultural Weather Network web site: accessed April 1, 2012, at http://ndawn.ndsu.nodak.edu/.

Norton, P., and Stamm, J., 2012, WRF dynamically downscaled simulation of projected climate in the Missouri River watershed-2000-2050: Boulder, Colorado, 13th Annual WRF User's Workshop, June 26-29, 2012.

Poiani, K.A., Johnson, W.C., Swanson, G.A., and Winter, T.C., 1996, Climate change and northern prairie wetlands - Simulations of long-term dynamics: Limnology and Oceanography, v. 41, p. 871-881. 
Rosenberry, D.O., Stannard, D.I., Winter, T.C., and Martinez, M.L., 2004, Comparison of 13 equations for determining evapotranspiration from a prairie wetland, Cottonwood Lake area, North Dakota, USA: Wetlands, v. 24, p. 483497.

Skagen, S.K., and Knopf, F.L., 1994, Migrating shorebirds and habitat dynamics at a prairie wetland complex: Wilson Bulletin, v. 106, p. 91-105.

Skamarock, W.C., Klemp, J.B., Dudhia, J., Gill, D.O., Barker, D.M., Duda, M.G., Huang, X., Wang, W., Powers, J.G., 2008, A description of the advanced research WRF Version 3: NCAR Technical Note, NCAR/TN-475+STR, Mesoscale and Microscale Meteorology Division, National Center for Atmospheric Research, Boulder, Colorado, 113 p.

Solomon, S., Qin, D., Manning, M., Chen, Z., Marquis, M., Averyt, K.B., Tignor, M., and Miller, H.L., eds., 2007, Climate change 2007: The physical science basis-Contribution of working group I to the Fourth Assessment Report of the Intergovernmental Panel on Climate Change: Cambridge, United Kingdom and New York, N.Y., Cambridge University Press, 996 p.

Stewart, R.E., and Kantrud, H.A., 1972, Vegetation of prairie potholes, North Dakota, in relation to quality of water and other environmental factors: U.S. Geological Survey Professional Paper 585-D, $36 \mathrm{p}$.

Su, M., Stolte, W.J., and van der Kamp, G., 2000, Modelling Canadian prairie wetland hydrology using a semi-distributed streamflow model: Hydrological Processes, v. 14, p. 2405-2422.

Swanson, G.A., Meyer, M.I., and Serie, J.R., 1974, Feeding ecology of breeding blue-winged teals: Journal of Wildlife Management, v. 38, p. 396-407.

Swanson, G.A., Winter, T.C., Adomaitis, V.A., and LaBaugh, J.W., 1988, Chemical characteristics of prairie lakes in south-central North Dakota-Their potential for influencing use by fish and wildlife: Washington, D.C., U.S. Fish and Wildlife Service, Fish and Wildlife Technical Report 18, $44 \mathrm{p}$.

Tchobanoglous, G., and Burton, F.L., 1991, Wastewater engineering; treatment, disposal, and reuse ( $3 \mathrm{~d}$ ed.): New York, N.Y., Metcalf \& Eddy, Inc., McGraw-Hill Inc., 1,024 p.

U.S. Fish and Wildlife Service, 2006, Comprehensive conservation plan-Long Lake National Wildlife Refuge Complex: Lakewood, Colorado, U.S. Department of the Interior, Fish and Wildlife Service, Mountain-Prairie Region, 276 p.

U.S. Fish and Wildlife Service, 2011, Comprehensive conservation plan-Bowdoin National Wildlife Refuge Complex: Lakewood, Colorado, U.S. Department of the Interior, Fish and Wildlife Service, Mountain-Prairie Region, 276 p.
U.S. Fish and Wildlife Service, 2012a, Refuge planning by region: accessed April 1, 2012, at http://www.fws.gov/ refuges/planning/comprehensive.html.

U.S. Fish and Wildlife Service, 2012b, National wildlife refuge system: accessed April 1, 2012, at http://www.fws.gov/ refuges/.

Vining, K.C., 2007, Water-balance model of a wetland on the Fort Berthold Reservation, North Dakota: U.S. Geological Survey Scientific Investigations Report 2007-5034, 15 p.

Winter, T.C., and Rosenberry, D.O., 1995, Evaluation of 11 equations for determining evaporation for a small lake in north central Unites States: Water Resources Research, v. 31, p. 983-993. 
Appendixes 
Appendix 1. Description of model and input variables for the water and salt balance (WSB) model.

[The WSB model Excel workbook contains ten worksheets, four of which are the primary data input worksheets: model, climate, flows and management, and bathymetry. A description of all worksheets is provided in appendix 2 . The 'model' sheet contains the water and salt balance (WSB) model. The 'climate' sheet includes climate data and evaporation model. The 'flows and management' sheet contains data relating to managed inflows, outflows, and water-control structure elevations. The 'bathymetry' sheet contains data relating depth, surface areas, volume, and pool elevation.NA, not applicable; NAVD 88, North American Vertical Datum of 1988; TDS, total dissolved solids; $\mu$ S/cm, microsiemens per centimeter at 25 degrees Celsius; WCS, water-control structure]

\begin{tabular}{|c|c|c|}
\hline Variable & Units & Variable definition/determination \\
\hline \multicolumn{3}{|r|}{ Model worksheet } \\
\hline Date & NA & month/day/year \\
\hline Pool elevation & feet (NAVD 88) & $\begin{array}{l}\text { pool elevation of impoundment / initial value from field measurement or estimate; } \\
\text { thereafter, value determined using lookup function (bathymetry worksheet) based } \\
\text { on 'final volume' and 'date' }\end{array}$ \\
\hline Depth & feet & $\begin{array}{l}\text { mean depth of impoundment / initial value determined using lookup function (ba- } \\
\text { thymetry worksheet) based on 'elevation'; thereafter, based on 'final volume' and } \\
\text { 'date' }\end{array}$ \\
\hline Surface area & acres & $\begin{array}{l}\text { inundated surface area of impoundment / initial value determined using lookup } \\
\text { function (bathymetry worksheet) based on 'elevation'; thereafter, based on 'final } \\
\text { volume' and 'date' }\end{array}$ \\
\hline Transition area & acres & $\begin{array}{l}\text { noninundated surface area of impoundment (based on maximum area) / initial value } \\
\text { determined using lookup function (bathymetry worksheet) based on 'elevation'; } \\
\text { thereafter, based on 'final volume' and 'date' }\end{array}$ \\
\hline Modeled volume & acre-feet & $\begin{array}{l}\text { calculated volume of impoundment based on total water inputs and losses / initial } \\
\text { value determined using lookup function (bathymetry worksheet) based on 'eleva- } \\
\text { tion'; thereafter, calculated by adding 'water input volume' and subtracting 'water } \\
\text { losses' from previous day's 'final volume' }\end{array}$ \\
\hline Final volume & acre-feet & $\begin{array}{l}\text { calculated volume of impoundment for daily time step; this variable "limits" the } \\
\text { 'modeled volume' based on 'WCS volume', if 'modeled volume' is greater than } \\
\text { 'WCS volume' the difference is considered outflow / value determine by subtract- } \\
\text { ing 'WCS volume' from 'modeled volume' }\end{array}$ \\
\hline Specific conductance & $\mu \mathrm{S} / \mathrm{cm}$ & $\begin{array}{l}\text { specific conductance of impoundment water / initial value from field measurement or } \\
\text { estimate; thereafter, calculated by converting 'TDS' using statistical relation (for } \\
\left.\text { example., fig. } 2 \text { [WSB model uses the following equation: } 3.16 \operatorname{TDS}^{0.898}\right] \text { ) }\end{array}$ \\
\hline TDS & $\begin{array}{l}\text { milligrams/ } \\
\text { liter }\end{array}$ & $\begin{array}{l}\text { total dissolved solids of impoundment water / initial value calculated by converting } \\
\text { 'specific conductance' using statistical relation (for example, fig. } 2 \text { [WSB model } \\
\text { uses the following equation: } 0.319 \text { specific conductance }{ }^{1.1} \text { ]); thereafter, calculated } \\
\text { by dividing 'salt mass' by 'final volume' }\end{array}$ \\
\hline Salt mass & milligrams & $\begin{array}{l}\text { total mass of salt dissolved in impoundment water / initial value calculated by multi- } \\
\text { plying 'TDS' by 'modeled volume'; thereafter, mass is adjusted by adding 'inflow } \\
\text { salt mass' and subtracting 'outflow salt mass' }\end{array}$ \\
\hline Precipitation & inches & $\begin{array}{l}\text { measured precipitation / value determined using lookup function (climate worksheet) } \\
\text { based on 'date' }\end{array}$ \\
\hline Inflow volume & acre-feet & $\begin{array}{l}\text { managed (measured or estimated) inflow to impoundment / value determined using } \\
\text { lookup function (flows and management worksheet) based on 'date' }\end{array}$ \\
\hline $\begin{array}{l}\text { Inflow specific con- } \\
\text { ductance }\end{array}$ & $\mu \mathrm{S} / \mathrm{cm}$ & $\begin{array}{l}\text { specific conductance (measured or estimated) of 'inflow volume' / value determined } \\
\text { using lookup function (flows and management worksheet) based on 'date' }\end{array}$ \\
\hline Water input volume & acre-feet & $\begin{array}{l}\text { total daily water inputs to impoundment / calculated by adding 'inflow volume' and } \\
\text { 'precipitation' ('precipitation' is multiplied by 'surface area') }\end{array}$ \\
\hline Evapotranspiration & feet & $\begin{array}{l}\text { estimated evapotranspiration from impoundment / value determined using lookup } \\
\text { function (climate worksheet) based on 'date'; WSB model calculates evapotrans- } \\
\text { piration using the Jensen-Haise evaporation model, which requires air temperature } \\
\text { and solar radiation }\end{array}$ \\
\hline
\end{tabular}

Outflow volume acre-feet

managed (gaged or estimated) outflow from impoundment / value determined using lookup function (flows and management worksheet) based on 'date' 


\section{Appendix 1. Description of model and input variables for the water and salt balance (WSB) model.—Continued}

[The WSB model Excel workbook contains ten worksheets, four of which are the primary data input worksheets: model, climate, flows and management, and bathymetry. A description of all worksheets is provided in appendix 2 . The 'model' sheet contains the water and salt balance (WSB) model. The 'climate' sheet includes climate data and evaporation model. The 'flows and management' sheet contains data relating to managed inflows, outflows, and water-control structure elevations. The 'bathymetry' sheet contains data relating depth, surface areas, volume, and pool elevation.NA, not applicable; NAVD 88, North American Vertical Datum of 1988; TDS, total dissolved solids; $\mu$ S/cm, microsiemens per centimeter at 25 degrees Celsius; WCS, water-control structure]

\begin{tabular}{|c|c|c|}
\hline Variable & Units & Variable definition/determination \\
\hline \multicolumn{3}{|r|}{ Model worksheet-Continued } \\
\hline Water loss volume & acre-feet & $\begin{array}{l}\text { total daily (gaged and estimated) water losses from impoundment / calculated by add- } \\
\text { ing 'outflow volume' and 'evapotranspiration' ('evapotranspiration' is multiplied } \\
\text { by 'surface area') }\end{array}$ \\
\hline Inflow salt mass & milligrams & $\begin{array}{l}\text { total mass of salt dissolved in 'inflow volume' / calculated by converting 'specific } \\
\text { conductance' to 'TDS' using statistical relation (for example, fig. } 2 \text { [WSB model } \\
\text { uses the following equation: } 0.319 \text { specific conductance }{ }^{1.1} \text { ]); 'TDS' is multiplied by } \\
\text { 'inflow volume' }\end{array}$ \\
\hline WCS outflow & acre-feet & $\begin{array}{l}\text { volume of outflow based on water-control structure and pool elevations / calculated } \\
\text { by subtracting 'WCS volume' from 'modeled volume'; this variable is used only to } \\
\text { calculate mass of salts lost to 'uncontrolled' outflow }\end{array}$ \\
\hline Outflow salt mass & milligrams & $\begin{array}{l}\text { total mass of salt in 'outflow volume' / calculated by converting 'specific conduc- } \\
\text { tance' to 'TDS' using statistical relation (for example, fig. } 2 \text { [WSB model uses the } \\
\left.\text { following equation: } 0.319 \text { specific conductance }{ }^{1.1}\right] \text { ); 'TDS' is multiplied by 'outflow } \\
\text { volume' and 'WCS outflow' }\end{array}$ \\
\hline \multicolumn{3}{|r|}{ Bathymetry worksheet } \\
\hline Elevation & feet (NAVD 88) & surface (pool) elevation of impoundment \\
\hline Volume & acre-feet & volume of impoundment \\
\hline Surface area & acres & surface area of impoundment \\
\hline Mean depth & feet & mean depth of impoundment \\
\hline Exposed lakebed & acres & surface area of exposed lakebed (for example, mudflats) \\
\hline \multicolumn{3}{|r|}{ Climate worksheet } \\
\hline Precipitation & inches & total daily precipitation \\
\hline Air temperature & $\begin{array}{l}\text { degrees Fahren- } \\
\text { heit }\end{array}$ & mean daily air temperature \\
\hline Solar radiation & $\begin{array}{l}\text { calories/square } \\
\text { centimeter·day }\end{array}$ & mean daily solar radiation \\
\hline Jensen-Haise & inches & estimated daily evaporation based on Jensen-Haise model \\
\hline Evaporation & inches & $\begin{array}{l}\text { estimated daily evaporation; if estimated value is less than zero evaporation is set as } \\
\text { zero }\end{array}$ \\
\hline \multicolumn{3}{|r|}{ Flows and Management worksheet } \\
\hline Inflow volume & acre-feet & surface inflow (gaged or estimated) to impoundment \\
\hline $\begin{array}{l}\text { Inflow specific con- } \\
\text { ductance }\end{array}$ & $\mu \mathrm{S} / \mathrm{cm}$ & $\begin{array}{l}\text { measured or estimated specific conductance of 'inflow volume'; note: if there are } \\
\text { inflows from more than one source with differing conductivities the model will } \\
\text { have to be adjusted }\end{array}$ \\
\hline Outflow volume & acre-feet & measured or estimated surface outflow from impoundment \\
\hline WCS elevation & feet (NAVD 88) & water-control structure elevation \\
\hline WCS volume & acre-feet & impoundment volume based on 'WCS elevation' \\
\hline
\end{tabular}




\section{Appendix 2. Instructions for Using the Digital Water and Salt Balance Model for Managed Wetland Impoundments}

\section{Overview}

A digital water and salt balance (WSB) model was developed to simulate various habitat metrics for managed wetland impoundments. The WSB model was developed in Microsoft Excel 2010; thus, a basic proficiency with the program is beneficial. The WSB model is available at http://pubs.usgs. gov/sir/2013/5114/. The Excel workbook contains ten worksheets: (1) model variables, (2) input variables, (3) bathymetry, (4) climate, (5) flows and management, (6) starting values, (7) model, (8) graph 1, (9) graph 2, and (10) graph 3. Each worksheet variable is described in detail in appendix 1. The following paragraph provides a brief overview of each worksheet.

The 'model variables' sheet describes each model variable, specifies the unit of measure, and describes how the value is determined. The 'input variables' sheet lists and defines the variables for each input worksheet (bathymetry, climate, flows and management). The 'bathymetry' sheet contains the depth, surface area, and volume data; each variable is presented twice in this worksheet to facilitate various lookup functions from the model. The 'climate' sheet includes daily precipitation and any additional data or models required to calculate evaporation (for example, temperature, solar radiation). The 'flows and management' sheet includes daily water inflow (if managed), specific conductance of the inflow water, daily outflow (if managed), water-control structure elevation, and a maximum water volume based on the watercontrol structure elevation and bathymetric data. The 'starting values' sheet specifies specific conductance, total dissolved solids (TDS), and pool elevation for initial model conditions. The 'model' sheet contains the WSB model; all calculations and lookup functions are embedded in the cell formulas and described in appendix 1. The three 'graph' sheets depict (1) daily specific conductance and pool elevation, (2) daily depth and surface areas (inundated, dry), and (3) daily mass of dissolved salts.

\section{Input Data}

Prior to running the model the following data must be incorporated. At a minimum, the model requires a rough surface area-capacity-depth curve, measured or modeled precipitation, and other data to support estimates of evaporation (for example, temperature, solar radiation). The WSB model calculates evaporation using the Jensen-Haise equation
(Jensen and Haise, 1963; McGuinness and Bordne, 1972; Rosenberry and others, 2004), but other equations or methods (for example, pan evaporation) can be easily substituted. Estimates of managed or natural inflows from canals and rivers are required, as are estimates of any managed outflows not accounted for by the primary water-control structure (for example, pumping). At a minimum, the WSB model requires elevation of the water-control structure to calculate surface outflows; however, when available, a stage-discharge curve will increase the accuracy of outflow rates. The model relies on a statistical relation (for example, fig. 2) to convert specific conductance to TDS, and vice-versa. Therefore, this relation must be specified by using site-specific data or selecting an appropriate model from existing literature. The WSB model incorporates the conversion model presented by Kendy (1999). Lastly, specific conductance and pool elevation are required to set initial model conditions.

\section{Model Setup}

To run the model a user must first adapt the WSB model to a specific site following five general steps: (1) Insert pool elevation, surface area, volume, and depth information into the 'bathymetry' sheet. Numerous model variables (depth, surface areas, pool elevation, volume) use a lookup function to obtain data from the 'bathymetry' sheet; thus, the cell range specified in the various lookup functions ('model' sheet) must be adjusted accordingly. (2) Insert daily data into the 'climate' sheet and insert any relevant information required to calculate evaporation (depends on method). Air temperature and solar radiation are required if using the Jensen-Haise equation associated with the WSB model. (3) Insert daily flow and watercontrol structure information into the 'flows and management' sheet. (4) Insert formula to convert specific conductance and TDS values into all appropriate cells ('model' and 'starting values' sheets). (5) Insert specific conductance and pool elevation into the 'starting values' sheet.

Once the bathymetric, daily input, conversion model, and starting values data are inserted, adjust the date range in the 'model' sheet so that it matches the input data sheets. The first row in the 'model' sheet is unique because it reads-in data from the starting values sheet. All subsequent rows are similar and the second row can be "filled down" for all remaining rows (based on the date range). Similarly, adjust the axes (data and date) in the 'graph' sheets to match the data range in the 'model' sheet. 


\section{Adapting the Water and Salt Balance Model}

The model is formatted and structured to facilitate adaptation to specific impoundments that vary according to available data. If additional information is available, a variable column can simply be added and incorporated into the existing model structure. For example, if a stage-discharge curve is available to calculate surface outflows (for example, Sand Lake National Wildlife Refuge and Long Lake National Wildlife Refuge model validations), a column (and formula) can be added, and the resulting estimate can be added to the "outflow" variable. Similarly, if daily data are not available, the model can easily be adjusted to provide monthly output. With this simple and transparent structure, nearly any variable associated with the water and salt balance of an impoundment can be added (or subtracted) with minimal technical programming. 
Publishing support provided by:

Rolla and Lafayette Publishing Service Centers

For more information concerning this publication, contact:

Director, USGS Northern Prairie Wildlife Research Center

8711 37th Street Southeast

Jamestown, North Dakota 58401

(701) 253-5553

Or visit the Northern Prairie Wildlife Research Center Web site at: http://www.npwrc.usgs.gov/ 



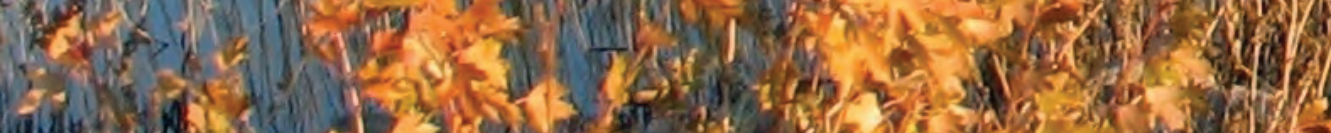

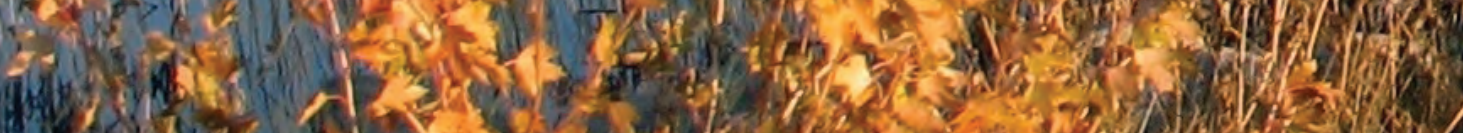

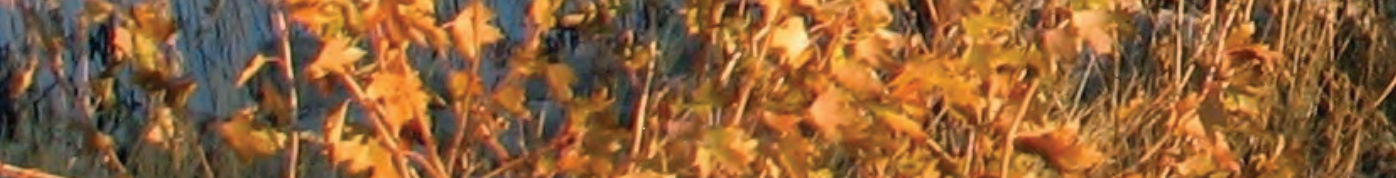

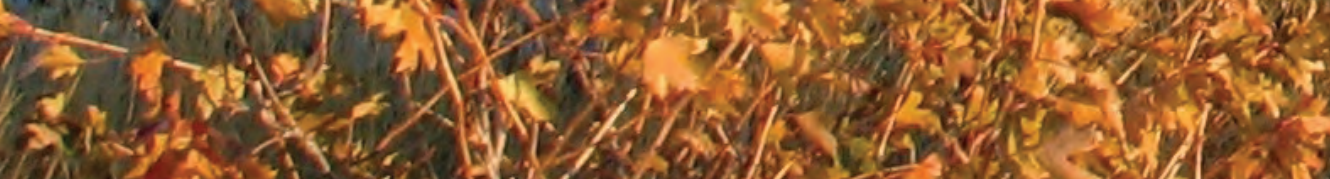
If $\rightarrow$ if

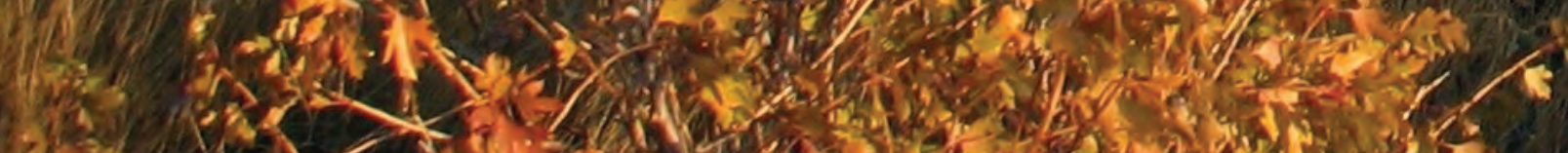

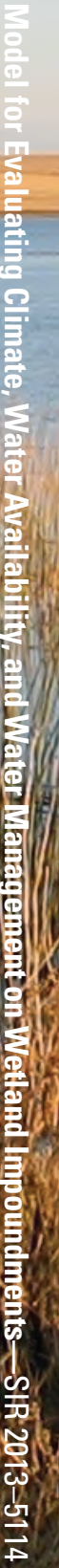

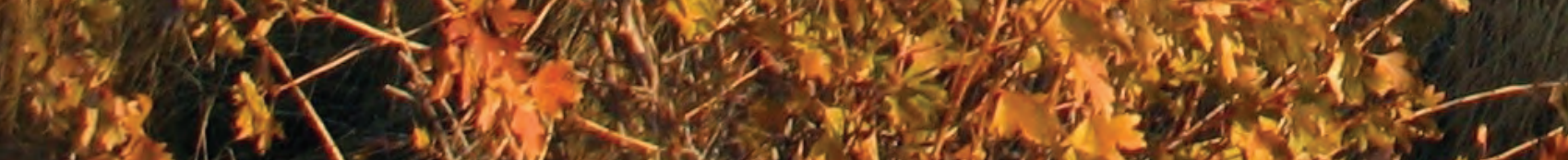

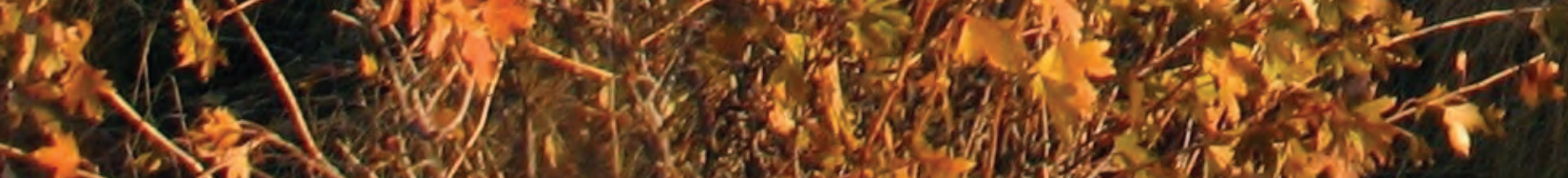
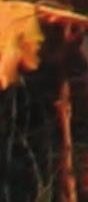